\title{
Microtubule-Associated Proteins with Regulatory Functions by Day and Pathological Potency at Night
}

\author{
Judit Oláh, Attila Lehotzky® ${ }^{\circledR}$, Sándor Szunyogh, Tibor Szénási, Ferenc Orosz and Judit Ovádi
}

Institute of Enzymology, Research Centre for Natural Sciences, Hungarian Academy of Sciences, 1117 Budapest, Hungary; olah.judit@ttk.mta.hu (J.O.); lehotzky.attila@ttk.mta.hu (A.L.); szunyogh.sandor@ttk.mta.hu (S.S.); szenasi.tibor@ttk.mta.hu (T.S.); orosz.ferenc@ttk.mta.hu (F.O.)

* Correspondence: ovadi.judit@ttk.mta.hu; Tel.: +36-1-3826-714

Received: 13 December 2019; Accepted: 2 February 2020; Published: 4 February 2020

\begin{abstract}
The sensing, integrating, and coordinating features of the eukaryotic cells are achieved by the complex ultrastructural arrays and multifarious functions of the cytoskeleton, including the microtubule network. Microtubules play crucial roles achieved by their decoration with proteins/enzymes as well as by posttranslational modifications. This review focuses on the Tubulin Polymerization Promoting Protein (TPPP/p25), a new microtubule associated protein, on its "regulatory functions by day and pathological functions at night". Physiologically, the moonlighting TPPP/p25 modulates the dynamics and stability of the microtubule network by bundling microtubules and enhancing the tubulin acetylation due to the inhibition of tubulin deacetylases. The optimal endogenous TPPP/p25 level is crucial for its physiological functions, to the differentiation of oligodendrocytes, which are the major constituents of the myelin sheath. Pathologically, TPPP/p25 forms toxic oligomers/aggregates with $\alpha$-synuclein in neurons and oligodendrocytes in Parkinson's disease and Multiple System Atrophy, respectively; and their complex is a potential therapeutic drug target. TPPP/p25-derived microtubule hyperacetylation counteracts uncontrolled cell division. All these issues reveal the anti-mitotic and $\alpha$-synuclein aggregation-promoting potency of TPPP/p25, consistent with the finding that Parkinson's disease patients have reduced risk for certain cancers.
\end{abstract}

Keywords: microtubule ultrastructure; TPPP; mitosis inhibition; tubulin acetylation; cancer; Parkinson's disease; inclusion; drug target

\section{Tubulin Polymerization Promoting Protein (TPPP/p25), A New Microtubule Regulatory Protein}

\subsection{Major Characteristics of the TPPP Family}

Microtubules are assembled from the highly conserved dimers of $\alpha$ - and $\beta$-tubulin and constitute the microtubule network, which is one of the major components of the eukaryotic cytoskeleton [1,2]. Microtubules are essential for cell polarity, cell shape, differentiation, and intracellular transport as well as for building of the mitotic spindles, which are the key structures in chromosome segregation during cell division. Microtubule systems can carry out a wide variety of functions at both physiological and pathological conditions that raises the following question: How can these evolutionarily-conserved proteins display multifarious functions? In living cells, microtubules interact with specific sets of microtubule-associated proteins (MAPs), including molecular motors, proteins regulating microtubule dynamics and stability and enzymes catalyzing metabolic and signaling pathways [3]. In fact, the specialized microtubule functions are determined to a large extent by the subset of partner proteins.

A brain-specific protein, p25, was discovered decades ago [4,5], which was later denoted as Tubulin Polymerization Promoting Protein (TPPP/p25) and identified as a new MAP as well as a hallmark of Parkinson's disease (PD) and other synucleinopathies [6,7]. This protein modulates the 
dynamics and stability of the microtubule system, aligns along the microtubule network and forms distinct microtubule ultrastructures depending on its intracellular level [8] (Figure 1).

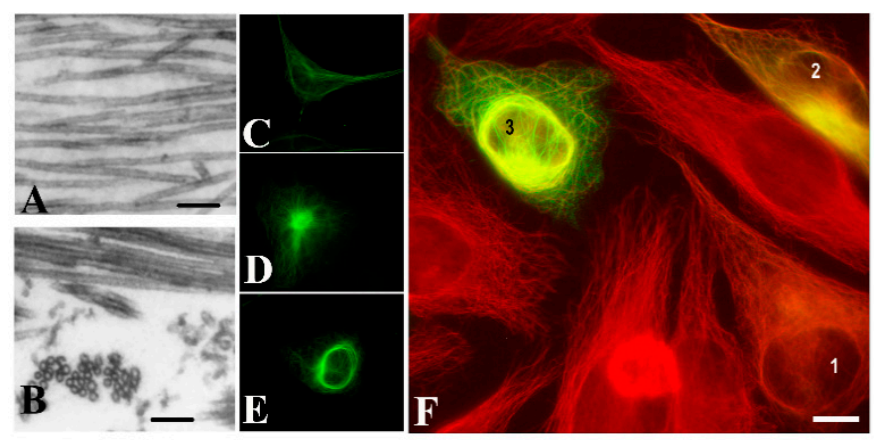

Figure 1. Tubulin Polymerization Promoting Protein (TPPP/p25)-derived ultrastructural organization of microtubules. Images of microtubules without or with human recombinant TPPP/p25: (A) control, (B) TPPP/p25-induced microtubule bundling, as visualized by electron microscopy. HeLa cells expressing pEGFP-TPPP/p25 (green): (C) control, (D) aggresome; (E) perinuclear cage; HeLa cells transiently transfected with EGFP-TPPP/p25 (green): (F) different expression levels produce distinct microtubule (red) ultrastructures: (1) alignment to the microtubule network, (2) aggresome formation, (3) perinuclear cage as visualized by immunofluorescence microscopy (selected from [9] and [8]). Scale bar: $100 \mathrm{~nm}$ $(\mathbf{A}, \mathbf{B}) ; 10 \mu \mathrm{m}(\mathbf{C}-\mathbf{F})$.

TPPP/p25 is an intrinsically disordered protein without a well-defined 3D structure, whose middle, highly flexible CORE region is straddled by the unstructured N- and C-termini [10]. Specific binding segments in the disordered TPPP/p25 have been identified, such as a zinc finger motif, a consensus GTP-binding domain and phosphorylation sites ([11] and references therein) (Figure 2).

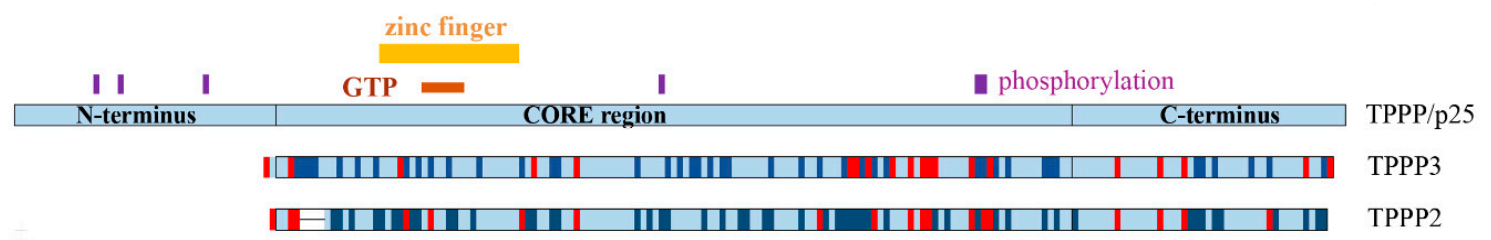

Figure 2. Scheme of the human TPPP/p25, ТPPP3, and TPPP2. Similar and different residues are indicated by dark blue and red, respectively. The zinc finger motif, a consensus GTP-binding segment and phosphorylation sites on TPPP/p25 are also indicated.

In vitro, TPPP/p25 is capable of inducing the polymerization of tubulin into normal, double-walled, and bundled microtubules [6]. At cellular level, TPPP/p25 co-localizes with the microtubule network in various cell lines, and its bundling activity protects the microtubules against depolymerizing agents $[6,8]$. The intrinsically disordered monomer TPPP/p25 is capable of dimerization stabilized by disulfide bridges [12]. The dimerization is crucial for its bundling activity; it induces the partial folding of the protein and the unstructured termini associate with other microtubules resulting in their cross-linking ([13,14] and references therein).

The interaction of TPPP/p25 and microtubules is very fast and dynamic, as demonstrated by fluorescence recovery after photobleaching experiments performed with normal rat kidney (NRK) cells expressing TPPP/p25 [8]. Moreover, altered localization of TPPP/p25 was detected during phases of mitosis (Figure 3). At interphase, TPPP/p25 localizes mainly on the microtubules throughout the cell: enriched TPPP/p25 can be found near to the centrosome, whereas less TPPP/p25 is present in the cell periphery. At the beginning of mitosis, before nuclear envelope breakdown, TPPP/p25 starts to detach from the microtubules. From prophase to late anaphase, free TPPP/p25 level is considerably higher in the cytoplasm. In metaphase and anaphase, TPPP/p25 accumulation is detectable only over the spindle microtubules and the centrosomes. The level of free TPPP/p25 decreases again at the 
telophase-cytokinesis transition and TPPP/p25 becomes preferentially enriched over the microtubules spanning the cytokinetic cleavage furrow [8]. These results indicate that TPPP/p25 binds stable interphase microtubules with high affinity (or its binding induces microtubule stabilization), whereas its association with dynamic M-phase microtubules is less efficient. The dynamic nature of the TPPP/p25 interaction with the microtubule network suggests the involvement of the protein in the reorganization of microtubule ultrastructures.

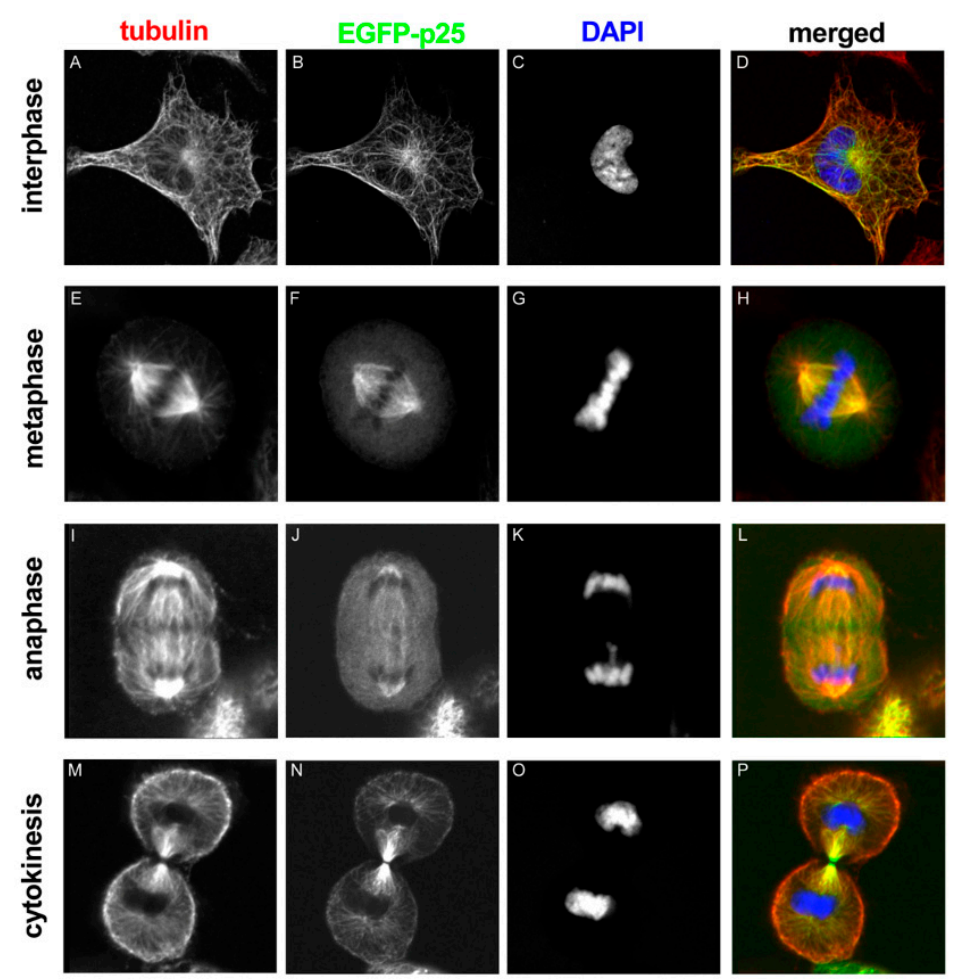

Figure 3. EGFP-TPPP/p25 localization in transfected NRK cells at different stages of mitosis. Tubulin, $\mathrm{TPPP} / \mathrm{p} 25$ and DNA are red, green and blue in the merged images, respectively [8].

We identified two human gene sequences, which encode homologous proteins displaying approximately $60 \%$ identity with TPPP/p25; they are N-terminal-free forms denoted as TPPP2/p18 and TPPP3/p20 (cf. Figure 2) [15]. For simplicity, TPPP/p25, TPPP2 and TPPP3 terms will be used without indicating the molecular mass of the paralog forms (18 and $20 \mathrm{kDa})$.

Both TPPP/p25 and TPPP3, but not TPPP2, have been isolated from bovine brain, and they associate to microtubules, displaying MAP-like features [6,15] (Figure 4). TPPP/p25 has been identified at protein level predominantly in oligodendrocytes (OLGs), neuropil and fiber-like structures of the CA3 hippocampal region $[5,16]$. TPPP2 has not be detected in adult mammalian brain [17]. The similarity of TPPP/p25 to TPPP3 is manifested in their intrinsically disordered characteristics; in addition, they are involved in developmental processes of the brain [16,18] and the musculoskeletal system [19], respectively. TPPP2 is involved in spermatogenesis [20] and its knockdown leads to infertility in mice [21]. The main characteristics of the three TPPP proteins can be found in databases, such as the HUGO Gene Nomenclature Database: TPPP/p25 [22], TPPP3 [23], and TPPP2 [24]. 


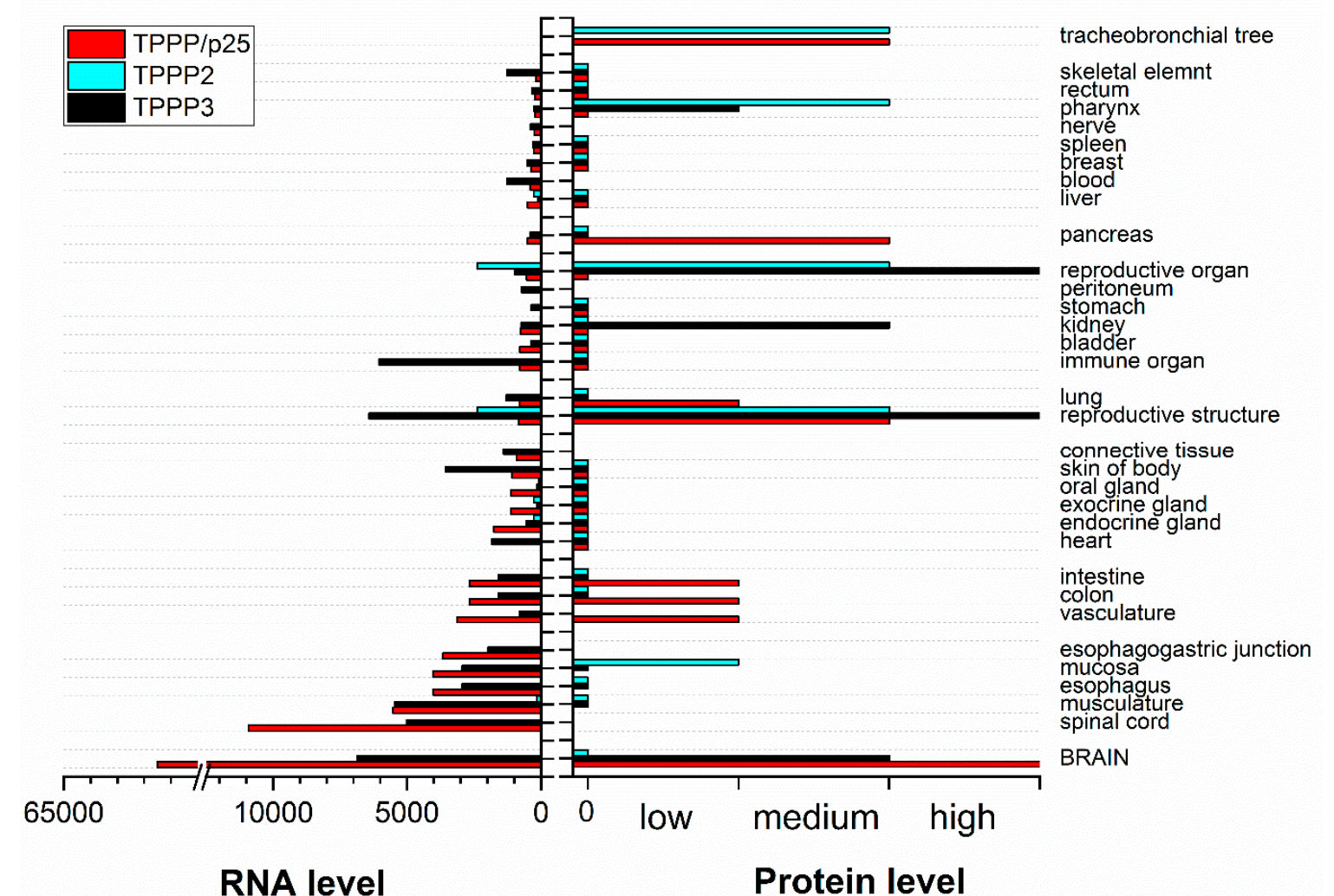

Figure 4. Summary of TPPP RNA and protein baseline expression data in normal human tissues based on RNA-seq expression data, Expression Atlas data and Human Protein Atlas normal tissue immunohistochemistry (https://www.targetvalidation.org) [25]. Columns without value indicate undetermined data.

\subsection{Expression and Function of TPPP/p25 in Human Brain}

TPPP/p25 is endogenously expressed in the OLGs of normal brain tissues, but not in astrocytes and neurons ([16] and references therein); in fact, its mRNA expression was found to be very low in neurons, astrocytes and microglia [26,27]. TPPP/p25 is primarily engaged in the development of projections of OLGs in the course of the differentiation that are the major constituents of the myelin ensheathing the axons [16]. The TPPP/p25 silencing by either siRNA or microRNA (miR-206) impeded the differentiation of OLGs, as we demonstrated on primary OLGs cells and in the OLG-like CG-4 cells culture [16]. The silencing posttranscriptionally reduces TPPP/p25 level and promotes the proliferation of progenitor cells, indicating the regulatory role of TPPP/p25 in the course of oligodendrogenesis [16].

Recently, Fu and co-workers [27] have identified TPPP/p25 as an OLG-enriched microtubule regulator that promotes microtubule growth from Golgi outposts and controls myelin sheath elongation, linking microtubule cytoarchitecture and myelination in the CNS. The complex cytoarchitecture of OLGs critical for myelin sheath elongation is dependent on microtubule nucleation by TPPP/p25 at Golgi outposts outside the cell body. The powerful effect of TPPP/p25 on the nucleation of the microtubules was established as well [27]. Aberrant microtubule branching, mixed microtubule polarity and shorter myelin sheaths were observed in primary OLGs of TPPP/p25 knockout mice. These mice exhibit hypomyelination with shorter, thinner myelin sheaths, which may indicate axonal transport dysfunction and degeneration. In addition, the TPPP/p25 knockout mice appeared to have breeding and motor coordination deficits [27]. Interestingly, the lack of TPPP/p25 in the embryonic brain and its presence in the postnatal brain was detected [5], coincidently with the start of myelination. These issues are in concern with our data that TPPP/p25 expression is a crucial factor of the differentiation of the OLGs [16]. Therefore, TPPP/p25 acts as a powerful nucleator of microtubules, and its propensity is 
important for the elongation of the microtubules for the formation of the myelin sheath by OLGs, not only for development, but also for myelin maintenance and plasticity in adult brain [27].

\subsection{TPPP Homologs Are Extensively Wide-Spread}

The vertebrate TPPPs are thought to have originated from the ancient invertebrate TPPP by two rounds of whole-genome duplication [28]. TPPP/p25 and TPPP3 are in closer phylogenetic connection with each other than either of them with TPPP2 [28]; this fact may explain their distinct functional propensities. Their microtubule binding/stabilizing function is evolutionarily conserved [29], and it is also present in invertebrates. The only TPPP of the fruit fly, Drosophila melanogaster [30], and that of the early branching animal, the sponge Suberites domuncula [29], promote microtubule bundling and polymerization potency. It was also shown that the region responsible for tubulin binding is the same in the sponge TPPP and the human TPPP/p25 proteins [29]. At lower organization level, this region is missing from TPPPs, however, a recent study in eukaryotic green alga, Chlamydomonas reinhardtii, demonstrated that the TPPP orthologue of the algae, the FAP265 protein, localizes at the basal bodies and in the flagella of vegetative Chlamydomonas cells that is essential for flagellar reassembly [31]. Since flagella or cilia are microtubule-based organelles, this finding suggests that the algal orthologue is also a microtubule-binding protein. According to bioinformatic analysis, there is a close phylogenetic connection between the presence of cilia/flagella and the occurrence of TPPP proteins [32].

Recently, the phenotypic identification and functional characterization of the Drosophila TPPP homolog named Ringmaker (Ringer; CG45057) have been reported [30]. Ringer displays a temporally dynamic expression in neurons and later in midline glia during ventral nerve cord development [30]. In fact, Ringer has been found as a major regulator of axonal microtubule organization, which is crucially required for proper axonal cytoskeletal architecture and growth during development. TPPP3 in zebrafish has been implicated in axon outgrowth as well [33,34]. Phenotypic similarities and genetic interactions with vertebrate homolog MAP1B, Futsch, have been described, indicating that both Ringer and Futsch regulate synaptic microtubule organization likely via the acetylation level of the microtubule network [35]. All these studies performed on homologs close to mammalian TPPPs suggest the role of microtubules and their associated proteins in synapse growth and organization.

$\mathrm{TPPP} / \mathrm{p} 25$ localization in nerve terminals of mice and human retina has been identified; OLGs in the myelin ensheathment of optic nerve, postsynaptic nerve terminals in striations of the inner plexiform layer and a subset of amacrine cells showed immunopositivity for TPPP/p25 both in mice and human eyes [36]. The co-localization of TPPP/p25 with acetylated tubulin was detected in amacrine cells, OLG cell bodies and in synapses in the inner plexiform layer that is rich in neuropil, in which the occurrence of TPPP/p25 has been detected. This finding suggests the role of TPPP/p25 in the organization and reorganization of synaptic connections and visual integration in the eye.

\subsection{Modulation of TPPP/p25 Expression at Transcriptional and Posttranscriptional Levels}

Genome stability is involved in the coordination of mitosis and cytokinesis, where dynamic microtubules capture and faithfully segregate chromosomes into daughter cells. Very recently, high-content RNAi screen revealed multiple roles for long noncoding RNAs (lncRNAs) in cell division. For example, a robust mitotic delay was detected upon depletion of the chromatin-associated lncRNA, linc00899 [37]. The ncRNAs inhibit the translation by degradation of target RNA transcript; they have no potential to code proteins. With the development of RNA sequencing technologies and bioinformatics, it was shown that numerous ncRNAs influence expression levels via chromatin modification, transcription, and posttranscriptional processing; in addition, the abnormal expression of ncRNAs is associated with invasion, metastasis.

Extensive transcriptome analysis of linc00899-depleted cells suggested the interaction of linc00899, as lncRNA, with TPPP/p25 as a potential target that binds the genomic locus of TPPP/p25 and suppresses its transcription. In addition, the inhibition of binding of linc00899 to TPPP/p25 resulted in the upregulation of TPPP/p25 coupled with changes in the microtubule dynamics and delay in mitosis. 
Therefore, the linc0889-dependent suppression of TPPP/p25 can control the mitotic progression, and in fact, the microtubule behavior, with functional implications beyond cell division [37]. These findings are in agreement with our observations showing the anti-mitotic effect of TPPP/p25 (see Section 2.1) and suggest pharmacological relevance, since the down-regulated linc00899 has an anti-oncogenic effect.

\subsection{TPPP/p25-Derived Posttranslational Modifications of the Microtubule Network}

An emerging mechanism that can directly and selectively control the interactions/functions of the microtubule network is its posttranslational modification. Tubulin and microtubules are subject to a remarkable number of posttranslational modifications that have been known for many decades [38,39]. A number of enzymes involved in the catalysis of these modifications have been identified, however, understanding the roles of these modifications in determining the functions and properties of microtubules is still challenging. These modifications display considerable diversity in the intracellular milieu, which varies with development, differentiation, cell compartment, and cell cycle ([39] and references therein). The modifications affect not only the dynamics and stability of the microtubules, but also their interactions with other cellular components, which can produce specific ultrastructures, resulting in distinct physiological and pathological functions. Therefore, the understanding of cellular microtubule diversity is in the focus of recent research, including that in our laboratory.

Several known tubulin modifications have been detected on the microtubules of the cell division machinery, such as mitotic and meiotic spindles, midbody microtubules, and particularly on centrioles. The $\alpha$-tubulin detyrosination, largely catalyzed by vasohibins, is involved in many microtubule-related cellular events, such as spindle formation and chromosome segregation during mitosis [40]. Deregulated detyrosination is related to cancer [41,42], linking tubulin modification, vasohibin dysfunctions and cancer [43]. Acetylation and polyglutamylation are enriched on mitotic spindle microtubules, midbody microtubules, and centrioles; however, their functional contribution is yet to be elucidated in detail. Neurons present an interesting case, as they are the only known cell type in which tubulin posttranslational modifications are strongly enriched on most cytoskeletal microtubules [44]. The neuronal microtubule cytoskeleton is involved in neuronal differentiation coupled with the accumulation of polyglutamylation, which is considered a potential regulator of microtubule properties.

The discovery of the posttranslational regulation of the microtubule network significantly contributes to our understanding of their roles in human diseases as well $[39,45]$. In fact, the enzymes catalyzing posttranslational modifications are accessible targets for drug development [46], and small molecule inhibitors of tubulin-modifying enzymes are promising as candidate drugs for treating serious pathologies related to aberrant tubulin modifications.

The acetylation level of microtubules and other cytosolic proteins, such as cortactin, is controlled by the opposing enzyme activities of acetyltransferases and tubulin deacetylases [18,47-50]. Cytosolic tubulin deacetylases, which specifically target the Lys- 40 residue of $\alpha$-tubulin, are the histone deacetylase 6 (HDAC6) and the sirtuin-2 (SIRT2) [49,50]. HDAC6 is a zinc-dependent, Class II HDAC, while SIRT2 belongs to the Class III HDACs displaying NAD+-dependent activity. Rather interestingly, while HDAC6 inhibition leads to general microtubule hyperacetylation, the hyperacetylation induced by SIRT2 inhibition is limited to perinuclear microtubules, indicating that the two enzymes might recognize specific structural context [51]. HDAC6 is ubiquitously expressed and conserved in a wide range of cell types; moreover, it is also involved in the dynein-dependent trafficking pathway as a scaffold protein, providing a connection of the dynein complex and the microtubule network [52]. TPPP/p25 inhibits the activity of HDAC6, resulting in the hyperacetylation of the microtubule network [18]. The TPPP/p25-induced HDAC6 inhibition also influences the growth velocity of the microtubule plus ends as well as the cell motility [18].

Posttranslational modifications of TPPP/p25 have been detected as well [53,54]. The phosphorylation mediated by mitogen-activated protein kinase 1 and cyclin-dependent kinase 5 (on Thr14, Ser18, and Ser160) resulted in the loss of TPPP/p25-induced assembly into intact-like 
microtubules [53]. Similar effect was observed upon the phosphorylation of TPPP/p25 (on the Ser residues) by LIM kinase 1 [55]. The Rho-associated coiled coil kinase also phosphorylates TPPP/p25 at Ser32, Ser107, and Ser159 without affecting its tubulin polymerization-promoting activity, but inhibiting its interaction with HDAC6 and resulting in reduced microtubule acetylation $[56,57]$. Therefore, the phosphorylation of distinct sites of TPPP/p25 by different kinases may play a crucial role in its multifarious functions, including its mitotic regulatory activity (cf. Figure 2).

SIRT2, as a tubulin deacetylase [50], plays an essential role in mitosis, as suggested by its increased abundance during cell division $[58,59]$. SIRT2 is abundant in neurons, its level is relatively high in OLGs, the major constituent of the myelin sheath [60-63]. The inhibition of SIRT2 by TPPP/p25 manifests itself within the SIRT2-tubulin-TPPP/p25 ternary complex, the concentration-dependent formation of which was quantified by experimental-based mathematical modelling [64]. Co-localization of the SIRT2-TPPP/p25 complex with the microtubule network was visualized in HeLa cells by immunofluorescence microscopy using Bimolecular Fluorescence Complementation technology [64] (Figure 5). However, the TPPP/p25-associated microtubule ultrastructures appeared to be resistant against SIRT2 activity due to the inaccessibility of the acetylated Lys40 residue. It has been proposed that the structural and functional effects of TPPP/p25 on the tubulin deacetylase SIRT2 could provide the fine-tuning of the regulation of microtubule dynamics and stability [64].

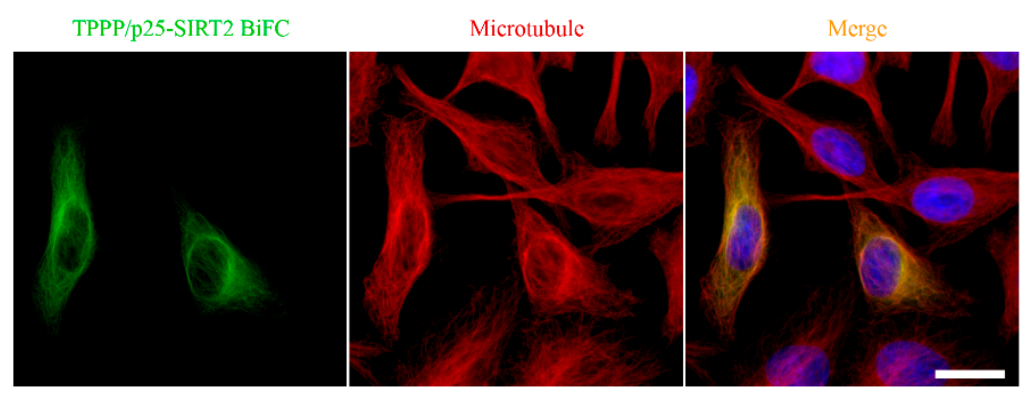

Figure 5. Localization of the SIRT2-TPPP/p25 complex on the microtubule network [64]. Scale bar: $10 \mu \mathrm{m}$.

SIRT2 silencing by siRNA was reported to increase tubulin acetylation and the complexity of cellular arborization in OLGs, while its over-expression displayed opposite effects [65,66]. However, the abundance of endogenous SIRT2 expression in cultured primary OLG precursors positively correlated with increased tubulin acetylation and differentiation, indicating its counterbalancing role to prevent uncontrolled acetylation [67]. The detailed mechanism of these complex processes is largely unknown; nevertheless, the regulation of microtubule stability and dynamics through the interplay of SIRT2 and $\mathrm{TPPP} / \mathrm{p} 25$ may represent an important regulatory mechanism in the cytoskeletal control either during oligodendrogenesis or in mature OLGs.

\section{TPPP/p25 in the Focus of Cancer Research}

\subsection{Influence of TPPP/p25 on the Reorganization of the Microtubule Systems}

One of our early results related to the potency of TPPP/p25 on the mitosis was obtained by a powerful in vivo method carried out on Drosophila embryos expressing GFP-tubulin fusion protein [9]. In this study, recombinant human TPPP/p25 was microinjected into the posterior pole of the cleavage embryos at the division anaphase, and the effect of TPPP/p25 on the mitosis was visualized by fluorescence confocal microscopy in the course of its diffusion [9]. TPPP/p25 inhibited mitotic spindle assembly and nuclear envelope breakdown without affecting other cellular events like centrosome replication and separation, microtubule nucleation. The specificity of the effect of TPPP/p25 on the mitosis inhibition was supported by the observation that GTP, as a regulatory ligand of the microtubule assembly, suspended the anti-mitotic effect of TPPP/p25. 
The influence of TPPP/p25 on the dynamics of the microtubule system was established by monitoring the growth velocity of the microtubules by time-lapse video microscopy using the GFP coupled plus-end tracking protein EB3 in living HeLa cell model [18]. The GFP-EB3 protein was visualized parallel with TPPP/p25 in HeLa cells transiently transfected with pDsRed-TPPP/p25 construct. The analysis of the microtubule growth velocities in the TPPP/p25-expressing cells revealed that the presence of TPPP/p25 produces reduced growth velocity [18]. Additional studies showed that the effect could be attributed, at least partly, to the enhanced tubulin acetylation resulted from the inhibition of HDAC 6 by TPPP/p25 [18]. The influence of TPPP/p25 on the cell motility investigated by time-lapse video microscopy using EGFP-TPPP/p25 showed that TPPP/p25 decreased the cell motility. The inhibitory effect on cell motility of TPPP/p25 overexpression was much weaker than that of paclitaxel, a microtubule stabilizing agent, but substantially stronger than that of a specific inhibitor of the tubulin deacetylase HDAC6 [18]. These findings may indicate the fine tuning of the stability of the microtubule network by TPPP/p25, which can counteract the uncontrolled cell division and display anti-cancer activity [68]. This issue is in concert with our early recognition that the expression of TPPP/p25 is negligible in cancer cell cultures, such as HeLa and many other commercial cell lines.

\subsection{Role of TPPP/p25 and TPPP3 in Cancerous Processes}

In normal brain, the microtubule network is of special importance, since it is actively involved in the maintenance of structural polarity of neurons, OLGs, and other cells, which is crucial for their physiological functions [69]. However, in the case of oligodendroglioma, a brain tumor, practically no TPPP/p25-positive cells could be detected in the brain tissue of the patients [70] (Table 1). In the case of pancreatic cancer, significantly lower TPPP/p25 expression was also found in tumor than in normal tissue [71,72]. Significantly lower TPPP/p25 expression was found also in liver tumor connected with poor prognosis [73]. The lower mRNA and/or protein expression of TPPP/p25 occurs much more frequently in the case of tumor cells in comparison to normal ones (Table 1).

Table 1. TPPPs in cancer.

\begin{tabular}{|c|c|c|c|c|c|}
\hline Cancer & TPPP & Level & Level & Other & \\
\hline Pancreatic & $\mathrm{TPPP} / \mathrm{p} 25$ & RNA & Low & & [71] \\
\hline Pancreatic & $\mathrm{TPPP} / \mathrm{p} 25$ & RNA & Low & & [72] \\
\hline Liver & $\mathrm{TPPP} / \mathrm{p} 25$ & RNA & Low & & [73] \\
\hline non-small cell Lung & $\mathrm{TPPP} / \mathrm{p} 25$ & DNA & & gain of $5 \mathrm{p} 15.33$ & [76] \\
\hline Bile duct & TPPP/p25 & DNA & & gain of $5 \mathrm{p} 15.33$ & [77] \\
\hline Bladder & $\mathrm{TPPP} / \mathrm{p} 25$ & DNA & & gain of $5 \mathrm{p} 15.33$ & [78] \\
\hline HeLa cells & ТРPР3 & RNA & & Depletion by RNAi suppressed cell proliferation & [79] \\
\hline non-small cell Lung & ТРРР3 & Protein & High & $\begin{array}{l}\text { Knockdown by shRNA inhibited cell } \\
\text { proliferation in vitro; depletion of TPPP3 } \\
\text { inhibited lung cancer growth in vivo }\end{array}$ & [82] \\
\hline Lung & ТРРР3 & Protein & High & & [83] \\
\hline Ovarian & ТРPP3 & RNA & High & 10x overexpression & [84] \\
\hline Clear cell sarcoma & ТРPР3 & $\begin{array}{c}\text { RNA, } \\
\text { Protein }\end{array}$ & High & & [85] \\
\hline $\begin{array}{l}\text { Pancreatic ductal } \\
\text { adenocarcinoma }\end{array}$ & ТРPР3 & Protein & & Higher ТРPР3 level indicates long survival & [86] \\
\hline
\end{tabular}


A recent study on pancreatic cancer further corroborated this view; moreover, for the first time, it provided a mechanistic view on the effect of TPPP/p25. Pancreatic cancer is a highly invasive cancer with poor prognosis, the development of which is inhibited by the transcription factor, Yin Yang 1 (YY1). Now, the key role of YY1 transcription factor in the suppression of invasion and metastasis has been reported in cancer cells ([74] and references therein). ChIP-sequencing studies showed that YY1 directly binds to the promoter region of TPPP/p25 in the case of pancreatic cancer. In vivo experiments revealed that $Y Y 1$ could inhibit the migration and invasion of pancreatic cancer cells by downregulating the expression of TPPP/p25 via p38/MAPK and PI3K/AKT pathways with undefined mechanism [74]. This finding indicates that TPPP/p25 is likely involved in the development of the pancreatic cancer by counteracting the inhibitory effect of $Y Y 1$ manifesting in the migration, invasion and angiogenesis. Thus, TPPP/p25 has been suggested to be a novel target for the treatment of pancreatic cancer.

Genome-wide association studies were successful in identifying genomic regions with robust evidence of associations with various cancers. One of these regions is located at chromosome 5p15.33, which was consistently shown in different studies ([75] and references therein). In parallel, it was shown that gains on chromosome region 5p15.33 are a common genetic event in some cancers: Bladder [78], lung [76], and bile duct [77]. Genes at 5p15.33 with potential candidate importance, including TPPP/p25, have been identified; e.g., the amplification of this region marks a major susceptibility locus in lung cancer, and a series of genes in this region may contribute to early stage lung tumorigenesis [76]. The importance of some of the genes of this region (TERT, CLPTM1L) were verified [87], but the relationship of TPPP/p25 to malignant tumors remains to be clarified. It was suggested that amplification of TPPP/p25 may confer a growth advantage to cancerous cells due to the abnormalities in tubulin assembly and spindle formation that are common features in malignant tumors [78]. An important question, namely, how do the copy changes correlate with mRNA expression needs to be answered. There is only one study concerning TPPP/p25, which shows lower mRNA expression in 167 lung cancer tissues [75] that was interpreted as: "The role of TPPP may be complicated, and additional studies are warranted to clarify the underlying mechanisms".

In contrast to the issue presented in relation of TPPP/p25, higher mRNA and/or protein expression of TPPP3 was found in tumor cells in comparison to normal ones in most cases investigated up to now, for example, in various lung, colorectal and ovarian tumors and in HeLa cells [79-84]. Depletion by RNAi or by shRNA inhibited tumor cell proliferation [79-82], migration and invasion [81]; inhibited lung cancer growth in vivo [82]; and survival rate was lower in patients with high expression of TPPP3 [81]. Table 1 summarizes the relationship of TPPP levels and the cancer types; however, according our knowledge, the nature of the apparently opposite effects has not been clarified.

\section{Role of TPPP/p25 in Neurological Disorders}

\section{1. $\alpha$-Synuclein and Related Pathologies}

$\alpha$-synuclein $(\mathrm{SYN})$ is a disordered protein with high conformational plasticity (chameleon propensity) [88-91]. Structurally, SYN comprises three regions: the N-terminal region involved in lipid binding; the highly hydrophobic central NAC region, which comprises the amyloidogenic part and serves as the building block of SYN aggregates; and the negatively charged unfolded C-terminus counteracting the aggregative potency of SYN $[89,90]$. The phosphorylation of Ser129 or nitration of Tyr125, Tyr133, and Tyr136 promotes the formation of SYN filaments or oligomers [92], while the phosphorylation of Ser87 and Tyr125 inhibits the in vitro fibrillation [93-95]. Although the physiological functions of SYN have not been described in detail, it displays crucial functions highly related to synaptic plasticity, synaptic vesicle pool maintenance, and dopamine metabolism $[90,96]$. The disordered SYN regulates the nucleation and dynamics of microtubules as a foldable microtubule dynamase [97]; in addition, it displays direct and indirect effects on microtubule stability in the pathogenesis of PD [98]. 
The overexpression of SYN leads to the formation of distinct types of assemblies, including oligomers, protofibrils, fibrils, and large Lewy bodies coupled with protein dysfunction, which may result in impaired intracellular trafficking or toxicity leading to cell death [99-101]. SYN has been identified as the first causative gene of familial PD, the accumulation of which causes synucleinopathies including PD, dementia with Lewy bodies and multiple system atrophy (MSA) [90,101-104].

In normal brain, the two proteins, SYN and TPPP/p25, are expressed predominantly in distinct cell types: in neurons [105,106] and in OLGs [5,16], respectively. Notwithstanding, at pathological conditions, the two hallmark proteins are co-enriched and co-localized in Lewy bodies and glial cytoplasmic inclusion in PD and MSA, respectively [7,107-109]. The pathological complex formation of TPPP/p25 and SYN has been characterized at molecular and cellular levels [110-112] (Figure 6). These data indicate that TPPP/p25 [7], besides SYN [102,103], is also a hallmark protein of synucleinopathies.

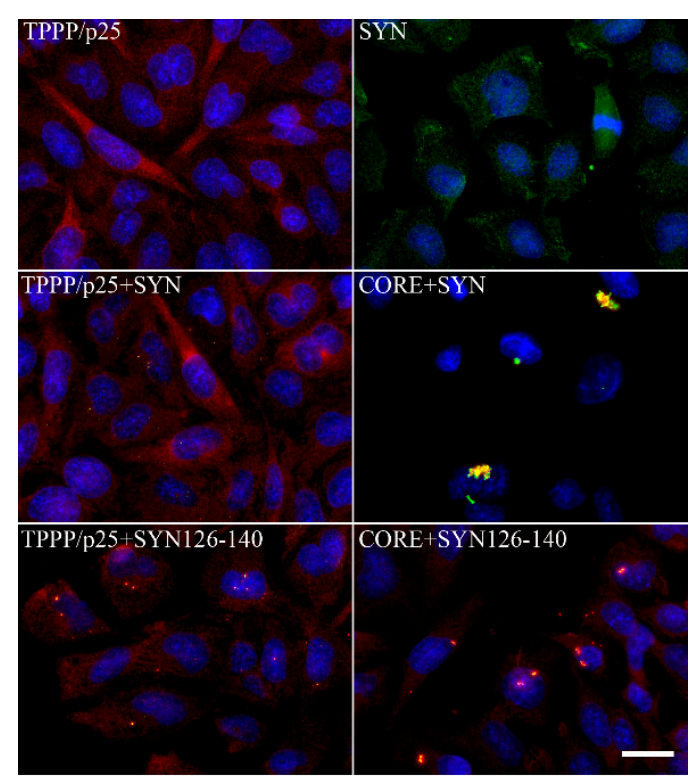

Figure 6. Intracellular aggregates of TPPP/p25 and $\alpha$-synuclein (SYN) and their truncated forms in $\mathrm{CHO} 10$ cells. Uptake of the SYN and/or TPPP/p25 forms from the medium following their premixing as detected by immunofluorescence microscopy: Full length or double truncated (CORE) TPPP/p25 and/or SYN, FITC SYN126-140 (adapted from [111]). Scale bar: $5 \mu \mathrm{m}$.

These issues have been further evolved by co-immunoprecipitation analysis carried out on HEK293T and oligodendroglial KG1C cell lines with ectopically expressed SYN and $\mathrm{TPPP} / \mathrm{p} 25$. The results revealed the specific interaction of the two proteins, furthermore, the TPPP/p25-promoted oligomerization of SYN [107]. Mavroeidi and his co-workers have shown that the TPPP/p25-overexpressing oligodendroglial cells taking up human pre-formed SYN fibrils form insoluble, highly aggregated, pathological assemblies leading to the disruption of the microtubule and myelin networks [113]. Moreover, the addition of these pre-formed fibrils evoked a dramatic increase in the level of endogenous SYN in OLGs, although its mRNA level remained unchanged. The pivotal roles of both the endogenous SYN and TPPP/p25 have been proposed in the progression of aggregation and the formation of glial cytoplasmic inclusion [113]. Early relocation of TPPP/p25 from the myelin sheath, as well as from the nucleus, to the cytoplasm of OLGs was reported in MSA [108,114]. Together, these data indicate the toxic potential of the pathological SYN-TPPP/p25 assembly.

The crucial question is how do these hallmark proteins, which are normally expressed in distinct cell types, form aggregates at pathological conditions in both neurons and OLGs?

The answer lies in the progression of the disease. SYN pathology through the brain over time suggests that there should be a physical transmission of pathological SYN from one area of the brain to 
another $([90,91]$ and references therein). Evidence for cell-to-cell transmission of SYN has arisen from both in vitro and in vivo studies; neuronal cells (donors) release SYN into the extracellular space, then it is taken up by various acceptor cells [115]. Its uptake by eukaryotic cells from the media has also been reported [110]. In addition, the presence of SYN, as well as its oligomeric or the Ser129-phosphorylated forms, has also been detected in the cerebrospinal fluid of PD patients [116,117]. Lower level of total SYN and enhanced concentration of oligomeric and phosphorylated SYN have been measured, suggesting that these species may serve as diagnostic biomarkers.

The uptake of TPPP/p25 from the media by eukaryotic cells has been proved as well $[110,111]$. The TPPP/p25 level was analyzed in the liquor of multiple sclerosis (MS) patients. MS is a chronic inflammatory demyelinating disease and loss of TPPP/p25-positive OLGs in demyelinated lesions in the brain of MS patients has been reported [118]. The analysis of the cerebrospinal fluid of the MS patients with either clinically isolated syndromes or relapsing-remitting MS showed increased level of TPPP/p25 as compared to the non-MS patients, indicating the potency of TPPP/p25 to be a biomarker of MS [119], but further efforts are needed to apply it in the clinical practice.

\subsection{TPPP/p25-Related Proteopathies beyond Synucleinopathies}

Proteopathies, such as Alzheimer's or Huntington's diseases, are different than synucleinopathies (PD and MSA), but they still display common features, such as the accumulation of protein aggregates. In medicine, the term proteopathies/conformational disease refers to a class of diseases in which certain proteins become structurally abnormal, fail to fold normal conformation, lose their physiological functions and become toxic; thereby these protein species disrupt the function of cells [120,121]. The aggregation-prone disordered hallmark proteins of these diseases can coexist in the diseased brain, raising the possibility of cross-seeding of one amyloidogenic protein by aggregated states of unrelated proteins [90,122]. TPPP/p25 interacts with $\beta$-amyloid and promotes the formation of aggregates [123]. Indeed, partial co-localization of $\beta$-amyloid and TPPP/p25 has been detected in the case of diffuse Lewy body disease with Alzheimer's disease, denoted as mixed-type pathology [7]. TPPP/p25 was also found to accumulate in intraneuronal granules and fibrous structures in hippocampus in the case of Alzheimer's disease [124]. In addition, characteristic pathological protein deposits have been identified in the case of MSA and tauopathy denoted as oligodendroglial proteinopathy. Its distinct features are as follows: "More co-localization of SYN than Tau with TPPP/p25, more obvious loss of OLG density in MSA, but more prominent association of Tau protein inclusions in globular glial tauopathy" [125]. Nevertheless, the direct interaction of Tau with SYN and the partial co-localization of phospho-Tau with TPPP/p25 have been reported as well $[125,126]$.

Tau protein is a well-characterized MAP that is tightly bound to the microtubules and stabilizes their 3D structure in eukaryotes ([127]. It is abundant in neurons, but also expressed in OLGs ([128] and references therein). TPPP/p25, as a MAP, is crucial for the decoration of the microtubule network; its expression is indispensable for the differentiation of the OLGs [16]. Nevertheless, the nature of their binding to the microtubule network is distinct: while the binding of Tau is stable, that of TPPP/p25 is highly dynamic [8]. These and additional evidence have been reported for the involvement of the microtubule system in pathological processes. Fragmentation of stable microtubules and the depletion of dynamic ones coupled with impairment of axonal transport seem to be common in the early stages of the pathology of synucleinopathies [129,130]. In PD models, earlier destabilization of the microtubule network accompanied by microtubule reorienting and the block of axonal transport were often observed. The microtubule stabilizer Epothilone D rescued microtubule defects, while the microtubule-interacting peptide davunetide improved motor functions and reduced the aggregation of SYN in mouse models of PD $[129,130]$. Low tubulin acetylation level, along with a concomitant impairment in axonal transport, is a common pathological hallmark in several neurodegenerative diseases $[129,130]$. In these pathological processes, TPPP/p25 is indirectly involved by its inhibitory potency against tubulin deacetylation $[18,64]$. A plausible explanation for this issue is that hyperacetylation stabilizes the microtubule network and promotes the microtubule-dependent transportation of the small toxic aggregates, including SYN, 
leading to the formation of aggresome at the centrosome region. Consequently, the stabilization of microtubules may be a strategy for the treatment of synucleinopathies and cancers [131-133].

\subsection{Elimination of the Pathological Protein Species}

The precision of cellular processes is intrinsically limited, which implies that cells naturally commit errors; in addition, cells are exposed to a multitude of stresses, both internal and environmental, which can induce molecular damage. This occurs at DNA, RNA levels arising at transcriptional or post-transcriptional processing, as well as at the protein level caused by enriched unfolded/misfolded and/or assembled proteins. Protein knockout and silencing approaches, such as CRISPR/Cas9 genome editing and RNA interference, are frequently applied for the identification of protein function and for developing therapeutic strategies. Despite these advances, most silencing systems suffer from limitations and are not always feasible. Similarly, RNA interference approaches warrant prolonged treatments and can lead to and are often associated with off-target effects ([134] and references therein). The PROteasome TArgeting Chimera (PROTAC), a recently introduced technology, can overcome some of the limitations, since it degrades proteins in a spatiotemporal manner [135,136], as we have hijacked SIRT2 as a potential anti-cancer drug target [137].

Both the microtubule-dependent autophagy and the ubiquitin-proteasome pathways, as major constituents of the cellular quality control system, play key roles in the degradation of SYN and other unwanted proteins [138]. One important aspect of SYN-mediated toxicity is the interrelation of SYN abundance and proteasome dysfunction. The degradation of TPPP/p25 by the ubiquitin-proteasome system has been reported, it is inhibited by MG132, a well-established proteasome inhibitor [8]. Blocking proteasome function impaired the ability of the centrosome to form regular microtubule asters [139]. Proteasome inhibition affects the turnover of centrosome proteins and it might increase the cytoplasmic level of these proteins, leading to ectopic nucleation of microtubules in the cytoplasm and competition with centrosomal microtubule nucleation [139].

\subsection{Challenging Targeting of Moonlighting Proteins with Chameleon Features}

The arsenal of therapies for synucleinopathies includes L-Dopa, several dopamine agonists, and inhibitors of monoamine oxidase, as well as deep brain stimulation $[68,140]$. Small molecules with the capacity to impede/block the assembly of toxic SYN oligomers appear to be a promising approach in the search for disease-modifying anti-PD drugs and are under development [140-143]. Nevertheless, it has to be emphasized that the extent of SYN silencing should be carefully controlled, as its near complete loss may have adverse effects on dopaminergic cell function and integrity, as revealed by the SYN knockout studies [90].

The application of drugs targeting microtubule acetylation is considered a useful strategy for therapeutic intervention [133]. Recently, growing interest has been focused on the therapeutic potency of SIRT2 inhibitors not only in cancer therapy, but also in several neurodegenerative diseases, including PD [144]. SIRT2 inhibitors prevent SYN-mediated toxicity and change the inclusion morphology in cultured neuroglioma cell line, likely due to the enhanced acetylation level of the microtubule network. In addition, their protective effects against dopaminergic cell death, both in vitro and in a Drosophila model of PD, were observed [145]. Moreover, SIRT2 inhibition was found to counteract apoptotic cell death concomitant with increased numbers of insoluble SYN-positive inclusions in a cellular model of MSA [107], suggesting the ability of SIRT2 inhibitors to rescue SYN toxicity [107,145-148]. Since endogenous SIRT2 is predominantly found in the cytoplasm of oligodendroglia rather than in that of neurons [60-63], the inhibition of SIRT2 resulting in tubulin hyperacetylation can be considered as a potential therapeutic approach in MSA. Specific HDAC6 inhibitors also exerted neuroprotection, rescued transport defects in some PD models [130,149].

$\mathrm{PD}$ and other synucleinopathies represent an important group of neurodegenerative disorders. The hallmarks of these diseases are SYN and TPPP/p25; both proteins are disordered with chameleon characteristics and expressed distinctly in neurons and OLGs, respectively $[5,16,105,106]$; however, 
they are co-enriched and co-localized in pathological inclusions in the case of PD and MSA [7,107-109]. Both hallmark proteins are neomorphic moonlighting -in the sense that they have both physiological and pathological functions-and also have the chameleon features, that is, the high conformational plasticity $[88,150]$. Due to these unique structural and functional features, none of these hallmark proteins is an ideal drug target. However, there is an opportunity to overcome this difficulty: Targeting the SYN-TPPP/p25 complex existing exclusively at pathological conditions [110-112]. According to the new innovative strategy evaluated recently in our lab, the interface of the pathological complex should be targeted for the inhibition and/or destruction of TPPP/p25 and SYN assemblies [110-112]. This strategy offers double advantages: The uncomplexed species retain their physiological functions and the toxic side effects are diminished by the selective inhibition of the pathological complex formation (Figure 7).

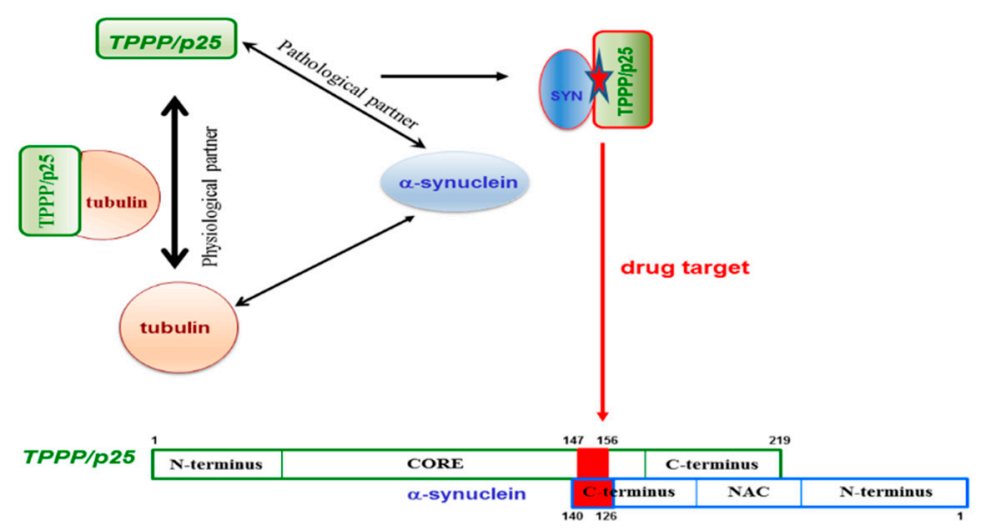

Figure 7. The interface of the pathological TPPP/p25-SYN complex as a specific drug target.

To achieve the task, the binding surface of the SYN-TPPP/p25 pathological complex has to be determined. The unstructured negatively charged C-terminal segment of SYN (95-140 aa) and a segment of the highly flexible CORE region of TPPP/p25 (147-156 aa) were identified to be involved in the heterocomplex formation [110-112]. Nevertheless, it has to be added that the deletions of the different segments of TPPP/p25 did not result in the lack of the interaction due to its special chameleon feature; however, it was not the case with SYN. These findings expose the challenges of targeting disordered, multifunctional proteins. The opportunity to fulfil the specific drug targeting task has been achieved; the 126-140 aa segment of SYN has been identified and validated at molecular and cellular levels, as a potential anti-PD drug target [110-112]. All these findings reveal that, although targeting chameleon proteins is a challenging task, however, the validation of a drug target can be achieved by identifying the interface of complexes of the partner proteins existing at the given pathological conditions.

\subsection{Are Cancer and Parkinson's Disease Connected?}

A new, exciting, and emerging area is the interrelationship of cancer and neurological disorders, the two apparently distinct disease groups [151-153]; the cancerous tumorigenesis and the neurological disorders can be characterized by uncontrolled cell division and uncontrolled cell assemblies, respectively ([68] and references therein). However, there are observations based mostly upon population and case-control studies that suggest an inverse relationship between the etiology of certain cancers and PD. Indeed, TPPP/p25, besides its anti-proliferative activity, displays a potency to induce SYN aggregation due to its uncontrolled intracellular level $[123,154]$. As illustrated in Figure 8, the non-physiological level of TPPP/p25 may lead to distinct disorders, either to cancerous or to neurodegenerative diseases ([68] and references therein). In light of these findings, it is not surprising that PD patients have reduced risk for various cancers. 


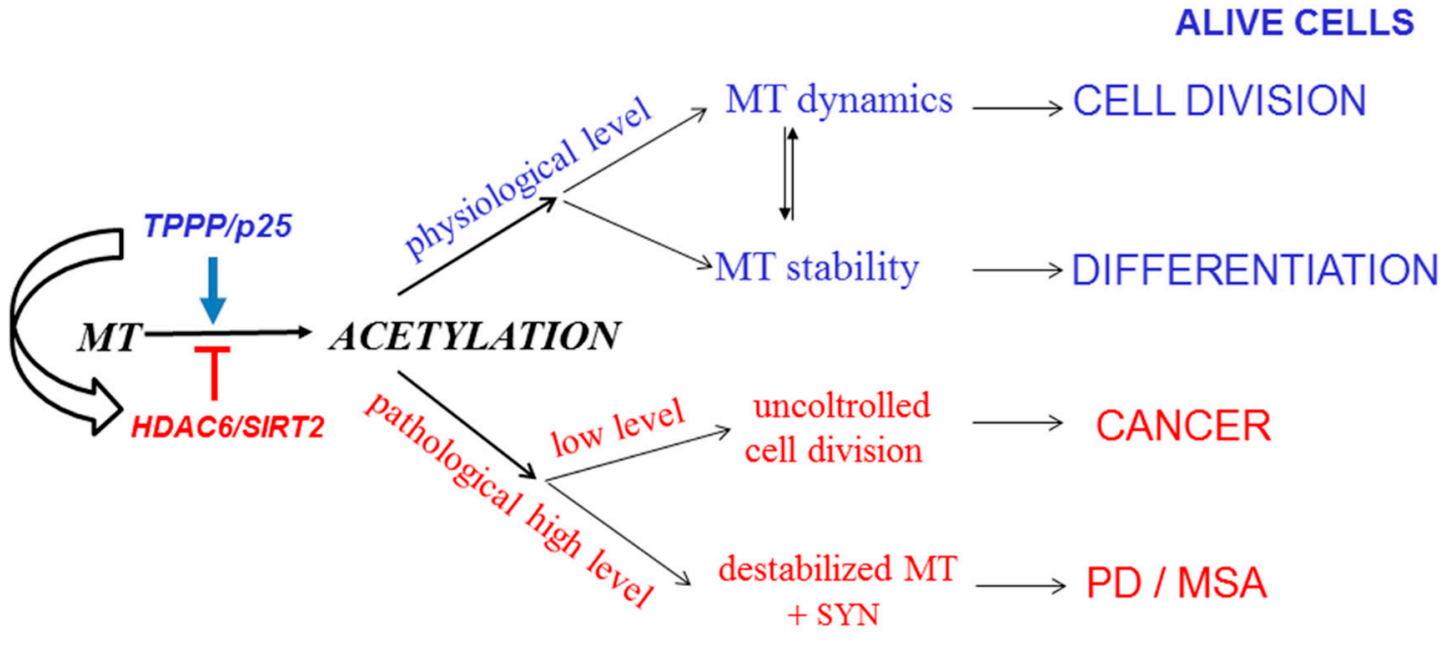

CELL DEATH

Figure 8. From regulation of microtubule acetylation to potential connection of Parkinson's disease (PD) and cancer. MT: microtubule. MSA: multiple system atrophy.

Author Contributions: All authors have read and agreed to the published version of the manuscript.

Funding: This research was funded by the European Concerted Research Action (COST) TD1406, the Hungarian National Research, Development and Innovation Office Grants OTKA [T-112144] and the Richter Gedeon Nyrt granted project 6567-19 403 VT to J. Ovádi; the János Bolyai Research Scholarship of the Hungarian Academy of Sciences to J. Oláh, and the Hungarian National Research, Development and Innovation Office Grants OTKA [PD-124061] to T. Szénási.

Acknowledgments: The authors wish to thank László Buday, director of the Institute of Enzymology for critical reading of the manuscript and the insightful discussion.

Conflicts of Interest: The authors declare no conflict of interest. The funders had no role in the design of the study; in the collection, analyses, or interpretation of data; in the writing of the manuscript, or in the decision to publish the results.

\section{References}

1. Conde, C.; Caceres, A. Microtubule assembly, organization and dynamics in axons and dendrites. Nat. Rev. Neurosci. 2009, 10, 319-332. [CrossRef] [PubMed]

2. De Forges, H.; Bouissou, A.; Perez, F. Interplay between microtubule dynamics and intracellular organization. Int. J. Biochem. Cell Biol. 2012, 44, 266-274. [CrossRef] [PubMed]

3. Bodakuntla, S.; Jijumon, A.S.; Villablanca, C.; Gonzalez-Billault, C.; Janke, C. Microtubule-Associated Proteins: Structuring the Cytoskeleton. Trends Cell Biol. 2019, 29, 804-819. [CrossRef] [PubMed]

4. Takahashi, M.; Tomizawa, K.; Ishiguro, K.; Sato, K.; Omori, A.; Sato, S.; Shiratsuchi, A.; Uchida, T.; Imahori, K. A novel brain-specific $25 \mathrm{kDa}$ protein (p25) is phosphorylated by a Ser/Thr-Pro kinase (TPK II) from tau protein kinase fractions. FEBS Lett. 1991, 289, 37-43. [CrossRef]

5. Takahashi, M.; Tomizawa, K.; Fujita, S.C.; Sato, K.; Uchida, T.; Imahori, K. A brain-specific protein p25 is localized and associated with oligodendrocytes, neuropil, and fiber-like structures of the CA hippocampal region in the rat brain. J. Neurochem. 1993, 60, 228-235. [CrossRef]

6. Hlavanda, E.; Kovacs, J.; Olah, J.; Orosz, F.; Medzihradszky, K.F.; Ovadi, J. Brain-specific p25 protein binds to tubulin and microtubules and induces aberrant microtubule assemblies at substoichiometric concentrations. Biochemistry 2002, 41, 8657-8664. [CrossRef]

7. Kovacs, G.G.; Laszlo, L.; Kovacs, J.; Jensen, P.H.; Lindersson, E.; Botond, G.; Molnar, T.; Perczel, A.; Hudecz, F.; Mezo, G.; et al. Natively unfolded tubulin polymerization promoting protein TPPP/p25 is a common marker of alpha-synucleinopathies. Neurobiol. Dis. 2004, 17, 155-162. [CrossRef]

8. Lehotzky, A.; Tirián, L.; Tőkési, N.; Lénárt, P.; Szabó, B.; Kovács, J.; Ovádi, J. Dynamic targeting of microtubules by TPPP/p25 affects cell survival. J. Cell Sci. 2004, 117, 6249-6259. [CrossRef] 
9. Tirian, L.; Hlavanda, E.; Olah, J.; Horvath, I.; Orosz, F.; Szabo, B.; Kovacs, J.; Szabad, J.; Ovadi, J. TPPP/p25 promotes tubulin assemblies and blocks mitotic spindle formation. Proc. Natl. Acad. Sci. USA 2003, 100, 13976-13981. [CrossRef]

10. Zotter, A.; Bodor, A.; Olah, J.; Hlavanda, E.; Orosz, F.; Perczel, A.; Ovadi, J. Disordered TPPP/p25 binds GTP and displays $\mathrm{Mg}^{2+}$-dependent GTPase activity. FEBS Lett. 2011, 585, 803-808. [CrossRef]

11. Olah, J.; Tokesi, N.; Lehotzky, A.; Orosz, F.; Ovadi, J. Moonlighting microtubule-associated proteins: Regulatory functions by day and pathological functions at night. Cytoskeleton 2013, 70, 677-685. [CrossRef]

12. Olah, J.; Zotter, A.; Hlavanda, E.; Szunyogh, S.; Orosz, F.; Szigeti, K.; Fidy, J.; Ovadi, J. Microtubule assembly-derived by dimerization of TPPP/p25. Evaluation of thermodynamic parameters for multiple equilibrium system from ITC data. Biochim. Biophys. Acta 2012, 1820, 785-794. [CrossRef] [PubMed]

13. Olah, J.; Szenasi, T.; Szunyogh, S.; Szabo, A.; Lehotzky, A.; Ovadi, J. Further evidence for microtubule-independent dimerization of TPPP/p25. Sci. Rep. 2017, 7, 40594. [CrossRef] [PubMed]

14. Olah, J.; Ovadi, J. Dual life of TPPP/p25 evolved in physiological and pathological conditions. Biochem. Soc. Trans. 2014, 42, 1762-1767. [CrossRef] [PubMed]

15. Vincze, O.; Tokesi, N.; Olah, J.; Hlavanda, E.; Zotter, A.; Horvath, I.; Lehotzky, A.; Tirian, L.; Medzihradszky, K.F.; Kovacs, J.; et al. Tubulin polymerization promoting proteins (TPPPs): Members of a new family with distinct structures and functions. Biochemistry 2006, 45, 13818-13826. [CrossRef]

16. Lehotzky, A.; Lau, P.; Tokesi, N.; Muja, N.; Hudson, L.D.; Ovadi, J. Tubulin polymerization-promoting protein (TPPP/p25) is critical for oligodendrocyte differentiation. Glia 2010, 58, 157-168. [CrossRef]

17. Zhang, Z.; Wu, C.; Huang, W.; Wang, S.; Zhao, E.; Huang, Q.; Xie, Y.; Mao, Y. A novel human gene whose product shares homology with bovine brain-specific protein p25 is expressed in fetal brain but not in adult brain. J. Hum. Genet. 2002, 47, 266-268. [CrossRef]

18. Tokesi, N.; Lehotzky, A.; Horvath, I.; Szabo, B.; Olah, J.; Lau, P.; Ovadi, J. TPPP/p25 promotes tubulin acetylation by inhibiting histone deacetylase 6. J. Biol. Chem. 2010, 285, 17896-17906. [CrossRef]

19. Staverosky, J.A.; Pryce, B.A.; Watson, S.S.; Schweitzer, R. Tubulin polymerization-promoting protein family member 3, Tppp3, is a specific marker of the differentiating tendon sheath and synovial joints. Dev. Dyn. 2009, 238, 685-692. [CrossRef]

20. Liu, M.; Hu, Z.; Qi, L.; Wang, J.; Zhou, T.; Guo, Y.; Zeng, Y.; Zheng, B.; Wu, Y.; Zhang, P.; et al. Scanning of novel cancer/testis proteins by human testis proteomic analysis. Proteomics 2013, 13, 1200-1210. [CrossRef]

21. Zhu, F.; Yan, P.; Zhang, J.; Cui, Y.; Zheng, M.; Cheng, Y.; Guo, Y.; Yang, X.; Guo, X.; Zhu, H. Deficiency of TPPP2, a factor linked to oligoasthenozoospermia, causes subfertility in male mice. J. Cell Mol. Med. 2019, 23, 2583-2594. [CrossRef]

22. HUGO Gene Nomenclature Database. TPPP/p25. Available online: https://www.genenames.org/data/genesymbol-report/\#!/hgnc_id/HGNC:24164 (accessed on 13 December 2019).

23. HUGO Gene Nomenclature Database. TPPP3. Available online: https://www.genenames.org/data/genesymbol-report/\#!/hgnc_id/HGNC:24162 (accessed on 13 December 2019).

24. HUGO Gene Nomenclature Database. TPPP2. Available online: https://www.genenames.org/data/genesymbol-report/\#!/hgnc_id/HGNC:19293 (accessed on 13 December 2019).

25. Carvalho-Silva, D.; Pierleoni, A.; Pignatelli, M.; Ong, C.; Fumis, L.; Karamanis, N.; Carmona, M.; Faulconbridge, A.; Hercules, A.; McAuley, E.; et al. Open Targets Platform: new developments and updates two years on. Nucleic Acids Res. 2019, 47, D1056-D1065. [CrossRef] [PubMed]

26. Goldbaum, O.; Jensen, P.H.; Richter-Landsberg, C. The expression of tubulin polymerization promoting protein TPPP/p25alpha is developmentally regulated in cultured rat brain oligodendrocytes and affected by proteolytic stress. Glia 2008, 56, 1736-1746. [CrossRef]

27. Fu, M.M.; McAlear, T.S.; Nguyen, H.; Oses-Prieto, J.A.; Valenzuela, A.; Shi, R.D.; Perrino, J.J.; Huang, T.T.; Burlingame, A.L.; Bechstedt, S.; et al. The Golgi Outpost Protein TPPP Nucleates Microtubules and Is Critical for Myelination. Cell 2019, 179, 132-146. [CrossRef] [PubMed]

28. Orosz, F. A fish-specific member of the TPPP protein family? J. Mol. Evol. 2012, 75, 55-72. [CrossRef] [PubMed]

29. Olah, J.; Szenasi, T.; Szabo, A.; Kovacs, K.; Low, P.; Stifanic, M.; Orosz, F. Tubulin Binding and Polymerization Promoting Properties of Tubulin Polymerization Promoting Proteins Are Evolutionarily Conserved. Biochemistry 2017, 56, 1017-1024. [CrossRef] [PubMed] 
30. Mino, R.E.; Rogers, S.L.; Risinger, A.L.; Rohena, C.; Banerjee, S.; Bhat, M.A. Drosophila Ringmaker regulates microtubule stabilization and axonal extension during embryonic development. J. Cell Sci. 2016, 129, 3282-3294. [CrossRef]

31. Tammana, D.; Tammana, T.V.S. Chlamydomonas FAP265 is a tubulin polymerization promoting protein, essential for flagellar reassembly and hatching of daughter cells from the sporangium. PLoS ONE 2017, 12, e0185108. [CrossRef]

32. Orosz, F.; Ovadi, J. TPPP orthologs are ciliary proteins. FEBS Lett. 2008, 582, 3757-3764. [CrossRef]

33. Aoki, M.; Segawa, H.; Naito, M.; Okamoto, H. Identification of possible downstream genes required for the extension of peripheral axons in primary sensory neurons. Biochem. Biophys. Res. Commun. 2014, 445, 357-362. [CrossRef]

34. Orosz, F. On the tubulin polymerization promoting proteins of zebrafish. Biochem. Biophys. Res. Commun. 2015, 457, 267-272. [CrossRef] [PubMed]

35. Shi, Q.; Lin, Y.Q.; Saliba, A.; Xie, J.; Neely, G.G.; Banerjee, S. Tubulin Polymerization Promoting Protein, Ringmaker, and MAP1B Homolog Futsch Coordinate Microtubule Organization and Synaptic Growth. Front. Cell Neurosci. 2019, 13, 192. [CrossRef] [PubMed]

36. Tripon, R.G.; Olah, J.; Nasir, T.; Csincsik, L.; Li, C.L.; Szunyogh, S.; Gong, H.; Flinn, J.M.; Ovadi, J.; Lengyel, I. Localization of the zinc binding tubulin polymerization promoting protein in the mice and human eye. J. Trace Elem. Med. Biol. 2018, 49, 222-230. [CrossRef]

37. Stojic, L.; Lun, A.T.L.; Mascalchi, P.; Ernst, C.; Redmond, A.M.; Mangei, J.; Barr, A.R.; Bousgouni, V.; Bakal, C.; Marioni, J.C.; et al. A high-content RNAi screen reveals multiple roles for long noncoding RNAs in cell division. bioRxiv 2019. [CrossRef]

38. Wloga, D.; Joachimiak, E.; Louka, P.; Gaertig, J. Posttranslational Modifications of Tubulin and Cilia. Cold Spring Harb. Perspect. Biol. 2017, 9, a028159. [CrossRef]

39. Magiera, M.M.; Singh, P.; Gadadhar, S.; Janke, C. Tubulin Posttranslational Modifications and Emerging Links to Human Disease. Cell 2018, 173, 1323-1327. [CrossRef]

40. Liao, S.; Rajendraprasad, G.; Wang, N.; Eibes, S.; Gao, J.; Yu, H.; Wu, G.; Tu, X.; Huang, H.; Barisic, M.; et al. Molecular basis of vasohibins-mediated detyrosination and its impact on spindle function and mitosis. Cell Res. 2019, 29, 533-547. [CrossRef]

41. Aillaud, C.; Bosc, C.; Peris, L.; Bosson, A.; Heemeryck, P.; Van Dijk, J.; Le Friec, J.; Boulan, B.; Vossier, F.; Sanman, L.E.; et al. Vasohibins/SVBP are tubulin carboxypeptidases (TCPs) that regulate neuron differentiation. Science 2017, 358, 1448-1453. [CrossRef]

42. Nieuwenhuis, J.; Adamopoulos, A.; Bleijerveld, O.B.; Mazouzi, A.; Stickel, E.; Celie, P.; Altelaar, M.; Knipscheer, P.; Perrakis, A.; Blomen, V.A.; et al. Vasohibins encode tubulin detyrosinating activity. Science 2017, 358, 1453-1456. [CrossRef]

43. Du, H.; Zhao, J.; Hai, L.; Wu, J.; Yi, H.; Shi, Y. The roles of vasohibin and its family members: Beyond angiogenesis modulators. Cancer Biol. Ther. 2017, 18, 827-832. [CrossRef]

44. Park, J.H.; Roll-Mecak, A. The tubulin code in neuronal polarity. Curr. Opin. Neurobiol. 2018, 51, 95-102. [CrossRef]

45. Li, L.; Yang, X.J. Tubulin acetylation: Responsible enzymes, biological functions and human diseases. Cell Mol. Life Sci. 2015, 72, 4237-4255. [CrossRef]

46. Huq, M.D.M.; Wei, L.-N. Pharmaceutical Sciences Encyclopedia Hoboken; John Wiley \& Sons, Inc.: Hoboken, NJ, USA, 2010; pp. 1-26.

47. Akella, J.S.; Wloga, D.; Kim, J.; Starostina, N.G.; Lyons-Abbott, S.; Morrissette, N.S.; Dougan, S.T.; Kipreos, E.T.; Gaertig, J. MEC-17 is an alpha-tubulin acetyltransferase. Nature 2010, 467, 218-222. [CrossRef]

48. Shida, T.; Cueva, J.G.; Xu, Z.; Goodman, M.B.; Nachury, M.V. The major alpha-tubulin K40 acetyltransferase alphaTAT1 promotes rapid ciliogenesis and efficient mechanosensation. Proc. Natl. Acad. Sci. USA 2010, 107, 21517-21522. [CrossRef]

49. Hubbert, C.; Guardiola, A.; Shao, R.; Kawaguchi, Y.; Ito, A.; Nixon, A.; Yoshida, M.; Wang, X.F.; Yao, T.P. HDAC6 is a microtubule-associated deacetylase. Nature 2002, 417, 455-458. [CrossRef]

50. North, B.J.; Marshall, B.L.; Borra, M.T.; Denu, J.M.; Verdin, E. The human Sir2 ortholog, SIRT2, is an NAD+-dependent tubulin deacetylase. Mol. Cell 2003, 11, 437-444. [CrossRef]

51. Skoge, R.H.; Ziegler, M. SIRT2 inactivation reveals a subset of hyperacetylated perinuclear microtubules inaccessible to HDAC6. J. Cell Sci. 2016, 129, 2972-2982. [CrossRef] 
52. Calderilla-Barbosa, L.; Seibenhener, M.L.; Du, Y.; Diaz-Meco, M.T.; Moscat, J.; Yan, J.; Wooten, M.W.; Wooten, M.C. Interaction of SQSTM1 with the motor protein dynein-SQSTM1 is required for normal dynein function and trafficking. J. Cell Sci. 2014, 127, 4052-4063. [CrossRef]

53. Hlavanda, E.; Klement, E.; Kokai, E.; Kovacs, J.; Vincze, O.; Tokesi, N.; Orosz, F.; Medzihradszky, K.F.; Dombradi, V.; Ovadi, J. Phosphorylation blocks the activity of tubulin polymerization-promoting protein (TPPP): Identification of sites targeted by different kinases. J. Biol. Chem. 2007, 282, 29531-29539. [CrossRef]

54. Kleinnijenhuis, A.J.; Hedegaard, C.; Lundvig, D.; Sundbye, S.; Issinger, O.G.; Jensen, O.N.; Jensen, P.H. Identification of multiple post-translational modifications in the porcine brain specific p25alpha. J. Neurochem. 2008, 106, 925-933. [CrossRef]

55. Acevedo, K.; Li, R.; Soo, P.; Suryadinata, R.; Sarcevic, B.; Valova, V.A.; Graham, M.E.; Robinson, P.J.; Bernard, $\mathrm{O}$. The phosphorylation of p25/TPPP by LIM kinase 1 inhibits its ability to assemble microtubules. Exp. Cell Res. 2007, 313, 4091-4106. [CrossRef]

56. Schofield, A.V.; Steel, R.; Bernard, O. Rho-associated coiled-coil kinase (ROCK) protein controls microtubule dynamics in a novel signaling pathway that regulates cell migration. J. Biol. Chem. 2012, 287, 43620-43629. [CrossRef] [PubMed]

57. Schofield, A.V.; Gamell, C.; Suryadinata, R.; Sarcevic, B.; Bernard, O. Tubulin polymerization promoting protein 1 (Tppp1) phosphorylation by Rho-associated coiled-coil kinase (rock) and cyclin-dependent kinase 1 (Cdk1) inhibits microtubule dynamics to increase cell proliferation. J. Biol Chem. 2013, 288, 7907-7917. [CrossRef] [PubMed]

58. Wang, Y.; Yang, J.; Hong, T.; Chen, X.; Cui, L. SIRT2: Controversy and multiple roles in disease and physiology. Ageing Res. Rev. 2019, 55, 100961. [CrossRef]

59. Dryden, S.C.; Nahhas, F.A.; Nowak, J.E.; Goustin, A.S.; Tainsky, M.A. Role for human SIRT2 NAD-dependent deacetylase activity in control of mitotic exit in the cell cycle. Mol. Cell Biol. 2003, 23, 3173-3185. [CrossRef] [PubMed]

60. Werner, H.B.; Kuhlmann, K.; Shen, S.; Uecker, M.; Schardt, A.; Dimova, K.; Orfaniotou, F.; Dhaunchak, A.; Brinkmann, B.G.; Mobius, W.; et al. Proteolipid protein is required for transport of sirtuin 2 into CNS myelin. J. Neurosci. 2007, 27, 7717-7730. [CrossRef]

61. Zhu, H.; Zhao, L.; Wang, E.; Dimova, N.; Liu, G.; Feng, Y.; Cambi, F. The QKI-PLP pathway controls SIRT2 abundance in CNS myelin. Glia 2012, 60, 69-82. [CrossRef]

62. Tang, B.L.; Chua, C.E. SIRT2, tubulin deacetylation, and oligodendroglia differentiation. Cell Motil. Cytoskelet. 2008, 65, 179-182. [CrossRef]

63. Southwood, C.M.; Peppi, M.; Dryden, S.; Tainsky, M.A.; Gow, A. Microtubule deacetylases, SirT2 and HDAC6, in the nervous system. Neurochem. Res. 2007, 32, 187-195. [CrossRef]

64. Szabó, A.; Olah, J.; Szunyogh, S.; Lehotzky, A.; Szenasi, T.; Csaplar, M.; Schiedel, M.; Low, P.; Jung, M.; Ovadi, J. Modulation Of Microtubule Acetylation By The Interplay Of TPPP/p25, SIRT2 And New Anticancer Agents With Anti-SIRT2 Potency. Sci. Rep. 2017, 7, 17070. [CrossRef]

65. Li, W.; Zhang, B.; Tang, J.; Cao, Q.; Wu, Y.; Wu, C.; Guo, J.; Ling, E.A.; Liang, F. Sirtuin 2, a mammalian homolog of yeast silent information regulator-2 longevity regulator, is an oligodendroglial protein that decelerates cell differentiation through deacetylating alpha-tubulin. J. Neurosci. 2007, 27, 2606-2616. [CrossRef] [PubMed]

66. Ji, S.; Doucette, J.R.; Nazarali, A.J. Sirt2 is a novel in vivo downstream target of Nkx2.2 and enhances oligodendroglial cell differentiation. J. Mol. Cell Biol. 2011, 3, 351-359. [CrossRef] [PubMed]

67. Nagai, T.; Ikeda, M.; Chiba, S.; Kanno, S.; Mizuno, K. Furry promotes acetylation of microtubules in the mitotic spindle by inhibition of SIRT2 tubulin deacetylase. J. Cell Sci. 2013, 126, 4369-4380. [CrossRef] [PubMed]

68. Olah, J.; Bertrand, P.; Ovadi, J. Role of the microtubule-associated TPPP/p25 in Parkinson's and related diseases and its therapeutic potential. Expert Rev. Proteom. 2017, 14, 301-309. [CrossRef]

69. Neukirchen, D.; Bradke, F. Neuronal polarization and the cytoskeleton. Semin. Cell Dev. Biol. 2011, 22, 825-833. [CrossRef]

70. Preusser, M.; Lehotzky, A.; Budka, H.; Ovadi, J.; Kovacs, G.G. TPPP/p25 in brain tumours: Expression in non-neoplastic oligodendrocytes but not in oligodendroglioma cells. Acta Neuropathol. 2007, 113, $213-215$. [CrossRef] 
71. Ishikawa, M.; Yoshida, K.; Yamashita, Y.; Ota, J.; Takada, S.; Kisanuki, H.; Koinuma, K.; Choi, Y.L.; Kaneda, R.; Iwao, T.; et al. Experimental trial for diagnosis of pancreatic ductal carcinoma based on gene expression profiles of pancreatic ductal cells. Cancer Sci. 2005, 96, 387-393. [CrossRef]

72. Badea, L.; Herlea, V.; Dima, S.O.; Dumitrascu, T.; Popescu, I. Combined gene expression analysis of whole-tissue and microdissected pancreatic ductal adenocarcinoma identifies genes specifically overexpressed in tumor epithelia. Hepatogastroenterology 2008, 55, 2016-2027.

73. Inokawa, Y.; Sonohara, F.; Kanda, M.; Hayashi, M.; Nishikawa, Y.; Sugimoto, H.; Kodera, Y.; Nomoto, S. Correlation Between Poor Prognosis and Lower TPPP Gene Expression in Hepatocellular Carcinoma. Anticancer Res. 2016, 36, 4639-4645. [CrossRef]

74. Chen, Q.; Yang, C.; Chen, L.; Zhang, J.J.; Ge, W.L.; Yuan, H.; Meng, L.D.; Huang, X.M.; Shen, P.; Miao, Y.; et al. YY1 targets tubulin polymerisation-promoting protein to inhibit migration, invasion and angiogenesis in pancreatic cancer via p38/MAPK and PI3K/AKT pathways. Br. J. Cancer 2019, 121, 912-921. [CrossRef]

75. Dong, J.; Cheng, Y.; Zhu, M.; Wen, Y.; Wang, C.; Wang, Y.; Geng, L.; Shen, W.; Liu, J.; Li, Z.; et al. Fine mapping of chromosome 5 p15.33 identifies novel lung cancer susceptibility loci in Han Chinese. Int. J. Cancer 2017, 141, 447-456. [CrossRef] [PubMed]

76. Kang, J.U.; Koo, S.H.; Kwon, K.C.; Park, J.W.; Kim, J.M. Gain at chromosomal region 5p15.33, containing TERT, is the most frequent genetic event in early stages of non-small cell lung cancer. Cancer Genet. Cytogenet. 2008, 182, 1-11. [CrossRef] [PubMed]

77. Kang, M.J.; Kim, J.; Jang, J.Y.; Park, T.; Lee, K.B.; Kim, S.W. 22q11-q13 as a hot spot for prediction of disease-free survival in bile duct cancer: Integrative analysis of copy number variations. Cancer Genet. 2014, 207, 57-69. [CrossRef] [PubMed]

78. Yamamoto, Y.; Chochi, Y.; Matsuyama, H.; Eguchi, S.; Kawauchi, S.; Furuya, T.; Oga, A.; Kang, J.J.; Naito, K.; Sasaki, K. Gain of 5p15.33 is associated with progression of bladder cancer. Oncology 2007, 72, 132-138. [CrossRef]

79. Zhou, W.; Wang, X.; Li, L.; Feng, X.; Yang, Z.; Zhang, W.; Hu, R. Depletion of tubulin polymerization promoting protein family member 3 suppresses HeLa cell proliferation. Mol. Cell Biochem. 2010, 333, 91-98. [CrossRef]

80. Zhou, W.; Li, J.; Wang, X.; Hu, R. Stable knockdown of TPPP3 by RNA interference in Lewis lung carcinoma cell inhibits tumor growth and metastasis. Mol. Cell Biochem. 2010, 343, 231-238. [CrossRef]

81. Ye, K.; Li, Y.; Zhao, W.; Wu, N.; Liu, N.; Li, R.; Chen, L.; He, M.; Lu, B.; Wang, X.; et al. Knockdown of Tubulin Polymerization Promoting Protein Family Member 3 inhibits cell proliferation and invasion in human colorectal cancer. J. Cancer 2017, 8, 1750-1758. [CrossRef]

82. Li, Y.; Xu, Y.; Ye, K.; Wu, N.; Li, J.; Liu, N.; He, M.; Lu, B.; Zhou, W.; Hu, R. Knockdown of Tubulin Polymerization Promoting Protein Family Member 3 Suppresses Proliferation and Induces Apoptosis in Non-Small-Cell Lung Cancer. J. Cancer 2016, 7, 1189-1196. [CrossRef]

83. Pastor, M.D.; Nogal, A.; Molina-Pinelo, S.; Melendez, R.; Salinas, A.; Gonzalez De la Pena, M.; Martin-Juan, J.; Corral, J.; Garcia-Carbonero, R.; Carnero, A.; et al. Identification of proteomic signatures associated with lung cancer and COPD. J. Proteom. 2013, 89, 227-237. [CrossRef]

84. King, E.R.; Tung, C.S.; Tsang, Y.T.; Zu, Z.; Lok, G.T.; Deavers, M.T.; Malpica, A.; Wolf, J.K.; Lu, K.H.; Birrer, M.J.; et al. The anterior gradient homolog 3 (AGR3) gene is associated with differentiation and survival in ovarian cancer. Am. J. Surg Pathol. 2011, 35, 904-912. [CrossRef]

85. Komura, S.; Ito, K.; Ohta, S.; Ukai, T.; Kabata, M.; Itakura, F.; Semi, K.; Matsuda, Y.; Hashimoto, K.; Shibata, H.; et al. Cell-type dependent enhancer binding of the EWS/ATF1 fusion gene in clear cell sarcomas. Nat. Commun. 2019, 10, 3999. [CrossRef]

86. Hu, D.; Ansari, D.; Pawlowski, K.; Zhou, Q.; Sasor, A.; Welinder, C.; Kristl, T.; Bauden, M.; Rezeli, M.; Jiang, Y.; et al. Proteomic analyses identify prognostic biomarkers for pancreatic ductal adenocarcinoma. Oncotarget 2018, 9, 9789-9807. [CrossRef]

87. Rafnar, T.; Sulem, P.; Stacey, S.N.; Geller, F.; Gudmundsson, J.; Sigurdsson, A.; Jakobsdottir, M.; Helgadottir, H.; Thorlacius, S.; Aben, K.K.; et al. Sequence variants at the TERT-CLPTM1L locus associate with many cancer types. Nat. Genet. 2009, 41, 221-227. [CrossRef]

88. Uversky, V.N. A protein-chameleon: Conformational plasticity of alpha-synuclein, a disordered protein involved in neurodegenerative disorders. J. Biomol. Struct. Dyn. 2003, 21, 211-234. [CrossRef] [PubMed] 
89. Bellucci, A.; Navarria, L.; Zaltieri, M.; Missale, C.; Spano, P. alpha-Synuclein synaptic pathology and its implications in the development of novel therapeutic approaches to cure Parkinson's disease. Brain Res. 2012, 1432, 95-113. [CrossRef] [PubMed]

90. Mochizuki, H.; Choong, C.J.; Masliah, E. A refined concept: alpha-synuclein dysregulation disease. Neurochem. Int. 2018, 119, 84-96. [CrossRef] [PubMed]

91. Henderson, M.X.; Trojanowski, J.Q.; Lee, V.M. alpha-Synuclein pathology in Parkinson's disease and related alpha-synucleinopathies. Neurosci. Lett. 2019, 709, 134316. [CrossRef]

92. Fujiwara, H.; Hasegawa, M.; Dohmae, N.; Kawashima, A.; Masliah, E.; Goldberg, M.S.; Shen, J.; Takio, K.; Iwatsubo, T. alpha-Synuclein is phosphorylated in synucleinopathy lesions. Nat. Cell Biol. 2002, 4, 160-164. [CrossRef] [PubMed]

93. Chen, L.; Periquet, M.; Wang, X.; Negro, A.; McLean, P.J.; Hyman, B.T.; Feany, M.B. Tyrosine and serine phosphorylation of alpha-synuclein have opposing effects on neurotoxicity and soluble oligomer formation. J. Clin. Investig. 2009, 119, 3257-3265. [PubMed]

94. Paleologou, K.E.; Schmid, A.W.; Rospigliosi, C.C.; Kim, H.Y.; Lamberto, G.R.; Fredenburg, R.A.; Lansbury, P.T., Jr.; Fernandez, C.O.; Eliezer, D.; Zweckstetter, M.; et al. Phosphorylation at Ser-129 but not the phosphomimics S129E/D inhibits the fibrillation of alpha-synuclein. J. Biol. Chem. 2008, 283, 16895-16905. [CrossRef] [PubMed]

95. Barrett, P.J.; Timothy Greenamyre, J. Post-translational modification of alpha-synuclein in Parkinson's disease. Brain Res. 2015, 1628, 247-253. [CrossRef] [PubMed]

96. Bisaglia, M.; Mammi, S.; Bubacco, L. Structural insights on physiological functions and pathological effects of alpha-synuclein. FASEB J. 2009, 23, 329-340. [CrossRef] [PubMed]

97. Cartelli, D.; Aliverti, A.; Barbiroli, A.; Santambrogio, C.; Ragg, E.M.; Casagrande, F.V.; Cantele, F.; Beltramone, S.; Marangon, J.; De Gregorio, C.; et al. alpha-Synuclein is a Novel Microtubule Dynamase. Sci. Rep. 2016, 6, 33289. [CrossRef] [PubMed]

98. Carnwath, T.; Mohammed, R.; Tsiang, D. The direct and indirect effects of alpha-synuclein on microtubule stability in the pathogenesis of Parkinson's disease. Neuropsychiatr. Dis. Treat. 2018, 14, 1685-1695. [CrossRef] [PubMed]

99. Vekrellis, K.; Xilouri, M.; Emmanouilidou, E.; Rideout, H.J.; Stefanis, L. Pathological roles of alpha-synuclein in neurological disorders. Lancet Neurol. 2011, 10, 1015-1025. [CrossRef]

100. Gandhi, J.; Antonelli, A.C.; Afridi, A.; Vatsia, S.; Joshi, G.; Romanov, V.; Murray, I.V.J.; Khan, S.A. Protein misfolding and aggregation in neurodegenerative diseases: A review of pathogeneses, novel detection strategies, and potential therapeutics. Rev. Neurosci. 2019, 30, 339-358. [CrossRef]

101. Kalia, L.V.; Lang, A.E. Parkinson's disease. Lancet 2015, 386, 896-912. [CrossRef]

102. Spillantini, M.G.; Schmidt, M.L.; Lee, V.M.; Trojanowski, J.Q.; Jakes, R.; Goedert, M. Alpha-synuclein in Lewy bodies. Nature 1997, 388, 839-840. [CrossRef]

103. Wakabayashi, K.; Yoshimoto, M.; Tsuji, S.; Takahashi, H. Alpha-synuclein immunoreactivity in glial cytoplasmic inclusions in multiple system atrophy. Neurosci. Lett. 1998, 249, 180-182. [CrossRef]

104. Papp, M.I.; Kahn, J.E.; Lantos, P.L. Glial cytoplasmic inclusions in the CNS of patients with multiple system atrophy (striatonigral degeneration, olivopontocerebellar atrophy and Shy-Drager syndrome). J. Neurol. Sci. 1989, 94, 79-100. [CrossRef]

105. Bates, C.A.; Zheng, W. Brain disposition of alpha-Synuclein: Roles of brain barrier systems and implications for Parkinson's disease. Fluids Barriers CNS 2014, 11, 17. [CrossRef] [PubMed]

106. Maroteaux, L.; Campanelli, J.T.; Scheller, R.H. Synuclein: A neuron-specific protein localized to the nucleus and presynaptic nerve terminal. J. Neurosci. 1988, 8, 2804-2815. [CrossRef] [PubMed]

107. Hasegawa, T.; Baba, T.; Kobayashi, M.; Konno, M.; Sugeno, N.; Kikuchi, A.; Itoyama, Y.; Takeda, A. Role of $\mathrm{TPPP} / \mathrm{p} 25$ on alpha-synuclein-mediated oligodendroglial degeneration and the protective effect of SIRT2 inhibition in a cellular model of multiple system atrophy. Neurochem. Int. 2010, 57, 857-866. [CrossRef] [PubMed]

108. Ota, K.; Obayashi, M.; Ozaki, K.; Ichinose, S.; Kakita, A.; Tada, M.; Takahashi, H.; Ando, N.; Eishi, Y.; Mizusawa, H.; et al. Relocation of p25alpha/tubulin polymerization promoting protein from the nucleus to the perinuclear cytoplasm in the oligodendroglia of sporadic and COQ2 mutant multiple system atrophy. Acta Neuropathol. Commun. 2014, 2, 136. 
109. Jellinger, K.A.; Wenning, G.K. Multiple system atrophy: Pathogenic mechanisms and biomarkers. J. Neural Transm. (Vienna) 2016, 123, 555-572. [CrossRef]

110. Tokesi, N.; Olah, J.; Hlavanda, E.; Szunyogh, S.; Szabo, A.; Babos, F.; Magyar, A.; Lehotzky, A.; Vass, E.; Ovadi, J. Identification of motives mediating alternative functions of the neomorphic moonlighting TPPP/p25. Biochim. Biophys. Acta 2014, 1842, 547-557. [CrossRef]

111. Szunyogh, S.; Olah, J.; Szenasi, T.; Szabo, A.; Ovadi, J. Targeting the interface of the pathological complex of alpha-synuclein and TPPP/p25. Biochim. Biophys Acta 2015, 1852, 2653-2661. [CrossRef]

112. Szenasi, T.; Olah, J.; Szabo, A.; Szunyogh, S.; Lang, A.; Perczel, A.; Lehotzky, A.; Uversky, V.N.; Ovadi, J. Challenging drug target for Parkinson's disease: Pathological complex of the chameleon TPPP/p25 and alpha-synuclein proteins. Biochim. Biophys. Acta 2017, 1863, 310-323. [CrossRef]

113. Mavroeidi, P.; Arvanitaki, F.; Karakitsou, A.K.; Vetsi, M.; Kloukina, I.; Zweckstetter, M.; Giller, K.; Becker, S.; Sorrentino, Z.A.; Giasson, B.I.; et al. Endogenous oligodendroglial alpha-synuclein and TPPP/p25alpha orchestrate alpha-synuclein pathology in experimental multiple system atrophy models. Acta Neuropathol. 2019, 138, 415-441. [CrossRef]

114. Song, Y.J.; Lundvig, D.M.; Huang, Y.; Gai, W.P.; Blumbergs, P.C.; Højrup, P.; Otzen, D.; Halliday, G.M.; Jensen, P.H. p25alpha relocalizes in oligodendroglia from myelin to cytoplasmic inclusions in multiple system atrophy. Am. J. Pathol. 2007, 171, 1291-1303. [CrossRef]

115. Danzer, K.M.; Kranich, L.R.; Ruf, W.P.; Cagsal-Getkin, O.; Winslow, A.R.; Zhu, L.; Vanderburg, C.R.; McLean, P.J. Exosomal cell-to-cell transmission of alpha synuclein oligomers. Mol. Neurodegener. 2012, 7, 42. [CrossRef]

116. Marques, O.; Outeiro, T.F. Alpha-synuclein: From secretion to dysfunction and death. Cell Death Dis. 2012, 3 , e350. [CrossRef] [PubMed]

117. Andersen, A.D.; Binzer, M.; Stenager, E.; Gramsbergen, J.B. Cerebrospinal fluid biomarkers for Parkinson's disease-A systematic review. Acta Neurol. Scand. 2017, 135, 34-56. [CrossRef] [PubMed]

118. Hoftberger, R.; Fink, S.; Aboul-Enein, F.; Botond, G.; Olah, J.; Berki, T.; Ovadi, J.; Lassmann, H.; Budka, H.; Kovacs, G.G. Tubulin polymerization promoting protein (TPPP/p25) as a marker for oligodendroglial changes in multiple sclerosis. Glia 2010, 58, 1847-1857. [CrossRef] [PubMed]

119. Vincze, O.; Olah, J.; Zadori, D.; Klivenyi, P.; Vecsei, L.; Ovadi, J. A new myelin protein, TPPP/p25, reduced in demyelinated lesions is enriched in cerebrospinal fluid of multiple sclerosis. Biochem. Biophys. Res. Commun. 2011, 409, 137-141. [CrossRef] [PubMed]

120. Choi, M.L.; Gandhi, S. Crucial role of protein oligomerization in the pathogenesis of Alzheimer's and Parkinson's diseases. FEBS J. 2018, 285, 3631-3644. [CrossRef]

121. Bourdenx, M.; Koulakiotis, N.S.; Sanoudou, D.; Bezard, E.; Dehay, B.; Tsarbopoulos, A. Protein aggregation and neurodegeneration in prototypical neurodegenerative diseases: Examples of amyloidopathies, tauopathies and synucleinopathies. Prog. Neurobiol. 2017, 155, 171-193. [CrossRef]

122. Irwin, D.J.; Lee, V.M.; Trojanowski, J.Q. Parkinson's disease dementia: Convergence of alpha-synuclein, tau and amyloid-beta pathologies. Nat. Rev. Neurosci. 2013, 14, 626-636. [CrossRef]

123. Olah, J.; Vincze, O.; Virok, D.; Simon, D.; Bozso, Z.; Tokesi, N.; Horvath, I.; Hlavanda, E.; Kovacs, J.; Magyar, A.; et al. Interactions of pathological hallmark proteins: Tubulin polymerization promoting protein/p25, beta-amyloid, and alpha-synuclein. J. Biol. Chem. 2011, 286, 34088-34100. [CrossRef]

124. Frykman, S.; Teranishi, Y.; Hur, J.Y.; Sandebring, A.; Yamamoto, N.G.; Ancarcrona, M.; Nishimura, T.; Winblad, B.; Bogdanovic, N.; Schedin-Weiss, S.; et al. Identification of two novel synaptic $\gamma$-secretase associated proteins that affect amyloid $\beta$-peptide levels without altering Notch processing. Neurochem. Int. 2012, 61, 108-118. [CrossRef]

125. Rohan, Z.; Milenkovic, I.; Lutz, M.I.; Matej, R.; Kovacs, G.G. Shared and Distinct Patterns of Oligodendroglial Response in alpha-Synucleinopathies and Tauopathies. J. Neuropathol. Exp. Neurol. 2016, 75, 1100-1109. [CrossRef] [PubMed]

126. Dasari, A.K.R.; Kayed, R.; Wi, S.; Lim, K.H. Tau Interacts with the C-Terminal Region of alpha-Synuclein, Promoting Formation of Toxic Aggregates with Distinct Molecular Conformations. Biochemistry 2019, 58, 2814-2821. [CrossRef]

127. Venkatramani, A.; Panda, D. Regulation of neuronal microtubule dynamics by tau: Implications for tauopathies. Int. J. Biol. Macromol. 2019, 133, 473-483. [CrossRef] 
128. LoPresti, P. Tau in Oligodendrocytes Takes Neurons in Sickness and in Health. Int. J. Mol. Sci. 2018, 19, 2408. [CrossRef] [PubMed]

129. Cartelli, D.; Cappelletti, G. Microtubule Destabilization Paves the Way to Parkinson's Disease. Mol. Neurobiol. 2017, 54, 6762-6774. [CrossRef] [PubMed]

130. Pellegrini, L.; Wetzel, A.; Granno, S.; Heaton, G.; Harvey, K. Back to the tubule: Microtubule dynamics in Parkinson's disease. Cell Mol. Life Sci. 2017, 74, 409-434. [CrossRef] [PubMed]

131. Hasegawa, T.; Matsuzaki, M.; Takeda, A.; Kikuchi, A.; Akita, H.; Perry, G.; Smith, M.A.; Itoyama, Y. Accelerated alpha-synuclein aggregation after differentiation of SH-SY5Y neuroblastoma cells. Brain Res. 2004, 1013, 51-59. [CrossRef]

132. Yan, J. Interplay between HDAC6 and its interacting partners: Essential roles in the aggresome-autophagy pathway and neurodegenerative diseases. DNA Cell Biol. 2014, 33, 567-580. [CrossRef]

133. Eira, J.; Silva, C.S.; Sousa, M.M.; Liz, M.A. The cytoskeleton as a novel therapeutic target for old neurodegenerative disorders. Prog. Neurobiol. 2016, 141, 61-82. [CrossRef]

134. Roth, S.; Fulcher, L.J.; Sapkota, G.P. Advances in targeted degradation of endogenous proteins. Cell Mol. Life Sci. 2019, 76, 2761-2777. [CrossRef]

135. Paiva, S.L.; Crews, C.M. Targeted protein degradation: Elements of PROTAC design. Curr. Opin. Chem. Biol. 2019, 50, 111-119. [CrossRef] [PubMed]

136. Sakamoto, K.M.; Kim, K.B.; Kumagai, A.; Mercurio, F.; Crews, C.M.; Deshaies, R.J. Protacs: Chimeric molecules that target proteins to the Skp1-Cullin-F box complex for ubiquitination and degradation. Proc. Natl. Acad. Sci. USA 2001, 98, 8554-8559. [CrossRef]

137. Schiedel, M.; Herp, D.; Hammelmann, S.; Swyter, S.; Lehotzky, A.; Robaa, D.; Oláh, J.; Ovádi, J.; Sippl, W.; Jung, M. Chemically Induced Degradation of Sirtuin 2 (Sirt2) by a Proteolysis Targeting Chimera (PROTAC) Based on Sirtuin Rearranging Ligands (SirReals). J. Med. Chem. 2018, 61, 482-491. [CrossRef]

138. Stefanis, L.; Emmanouilidou, E.; Pantazopoulou, M.; Kirik, D.; Vekrellis, K.; Tofaris, G.K. How is alpha-synuclein cleared from the cell? J. Neurochem. 2019, 150, 577-590. [CrossRef]

139. Didier, C.; Merdes, A.; Gairin, J.E.; Jabrane-Ferrat, N. Inhibition of proteasome activity impairs centrosome-dependent microtubule nucleation and organization. Mol. Biol. Cell 2008, 19, 1220-1229. [CrossRef]

140. Oertel, W.; Schulz, J.B. Current and experimental treatments of Parkinson disease: A guide for neuroscientists. J. Neurochem. 2016, 139 (Suppl. 1), 325-337. [CrossRef]

141. Jha, N.N.; Kumar, R.; Panigrahi, R.; Navalkar, A.; Ghosh, D.; Sahay, S.; Mondal, M.; Kumar, A.; Maji, S.K. Comparison of alpha-Synuclein Fibril Inhibition by Four Different Amyloid Inhibitors. ACS Chem. Neurosci. 2017, 8, 2722-2733. [CrossRef]

142. Savitt, D.; Jankovic, J. Targeting alpha-Synuclein in Parkinson's Disease: Progress Towards the Development of Disease-Modifying Therapeutics. Drugs 2019, 79, 797-810. [CrossRef]

143. O'Hara, D.M.; Kalia, S.K.; Kalia, L.V. Emerging disease-modifying strategies targeting alpha-synuclein for the treatment of Parkinson's disease. Br. J. Pharmacol. 2018, 175, 3080-3089. [CrossRef] [PubMed]

144. Kazantsev, A.G.; Thompson, L.M. Therapeutic application of histone deacetylase inhibitors for central nervous system disorders. Nat. Rev. Drug Discov. 2008, 7, 854-868. [CrossRef] [PubMed]

145. Outeiro, T.F.; Kontopoulos, E.; Altmann, S.M.; Kufareva, I.; Strathearn, K.E.; Amore, A.M.; Volk, C.B.; Maxwell, M.M.; Rochet, J.C.; McLean, P.J.; et al. Sirtuin 2 inhibitors rescue alpha-synuclein-mediated toxicity in models of Parkinson's disease. Science 2007, 317, 516-519. [CrossRef] [PubMed]

146. Chen, X.; Wales, P.; Quinti, L.; Zuo, F.; Moniot, S.; Herisson, F.; Rauf, N.A.; Wang, H.; Silverman, R.B.; Ayata, C.; et al. The sirtuin-2 inhibitor AK7 is neuroprotective in models of Parkinson's disease but not amyotrophic lateral sclerosis and cerebral ischemia. PLoS ONE 2015, 10, e0116919. [CrossRef] [PubMed]

147. De Oliveira, R.M.; Vicente Miranda, H.; Francelle, L.; Pinho, R.; Szego, E.M.; Martinho, R.; Munari, F.; Lazaro, D.F.; Moniot, S.; Guerreiro, P.; et al. The mechanism of sirtuin 2-mediated exacerbation of alpha-synuclein toxicity in models of Parkinson disease. PLoS Biol. 2017, 15, e2000374. [CrossRef] [PubMed]

148. Harrison, I.F.; Smith, A.D.; Dexter, D.T. Pathological histone acetylation in Parkinson's disease: Neuroprotection and inhibition of microglial activation through SIRT 2 inhibition. Neurosci. Lett. 2018, 666, 48-57. [CrossRef] [PubMed] 
149. Godena, V.K.; Brookes-Hocking, N.; Moller, A.; Shaw, G.; Oswald, M.; Sancho, R.M.; Miller, C.C.; Whitworth, A.J.; De Vos, K.J. Increasing microtubule acetylation rescues axonal transport and locomotor deficits caused by LRRK2 Roc-COR domain mutations. Nat. Commun. 2014, 5, 5245. [CrossRef]

150. Ovadi, J. Moonlighting proteins in neurological disorders. IUBMB Life 2011, 63, 453-456. [CrossRef]

151. Ganguli, M. Cancer and Dementia: It's Complicated. Alzheimer Dis. Assoc. Disord. 2015, 29, 177-182. [CrossRef]

152. Feng, D.D.; Cai, W.; Chen, X. The associations between Parkinson's disease and cancer: The plot thickens. Transl. Neurodegener. 2015, 4, 20. [CrossRef]

153. Plun-Favreau, H.; Lewis, P.A.; Hardy, J.; Martins, L.M.; Wood, N.W. Cancer and neurodegeneration: Between the devil and the deep blue sea. PLoS Genet. 2010, 6, e1001257. [CrossRef]

154. Lindersson, E.; Lundvig, D.; Petersen, C.; Madsen, P.; Nyengaard, J.R.; Hojrup, P.; Moos, T.; Otzen, D.; Gai, W.P.; Blumbergs, P.C.; et al. p25alpha Stimulates alpha-synuclein aggregation and is co-localized with aggregated alpha-synuclein in alpha-synucleinopathies. J. Biol. Chem. 2005, 280, 5703-5715. [CrossRef]

(C) 2020 by the authors. Licensee MDPI, Basel, Switzerland. This article is an open access article distributed under the terms and conditions of the Creative Commons Attribution (CC BY) license (http://creativecommons.org/licenses/by/4.0/). 